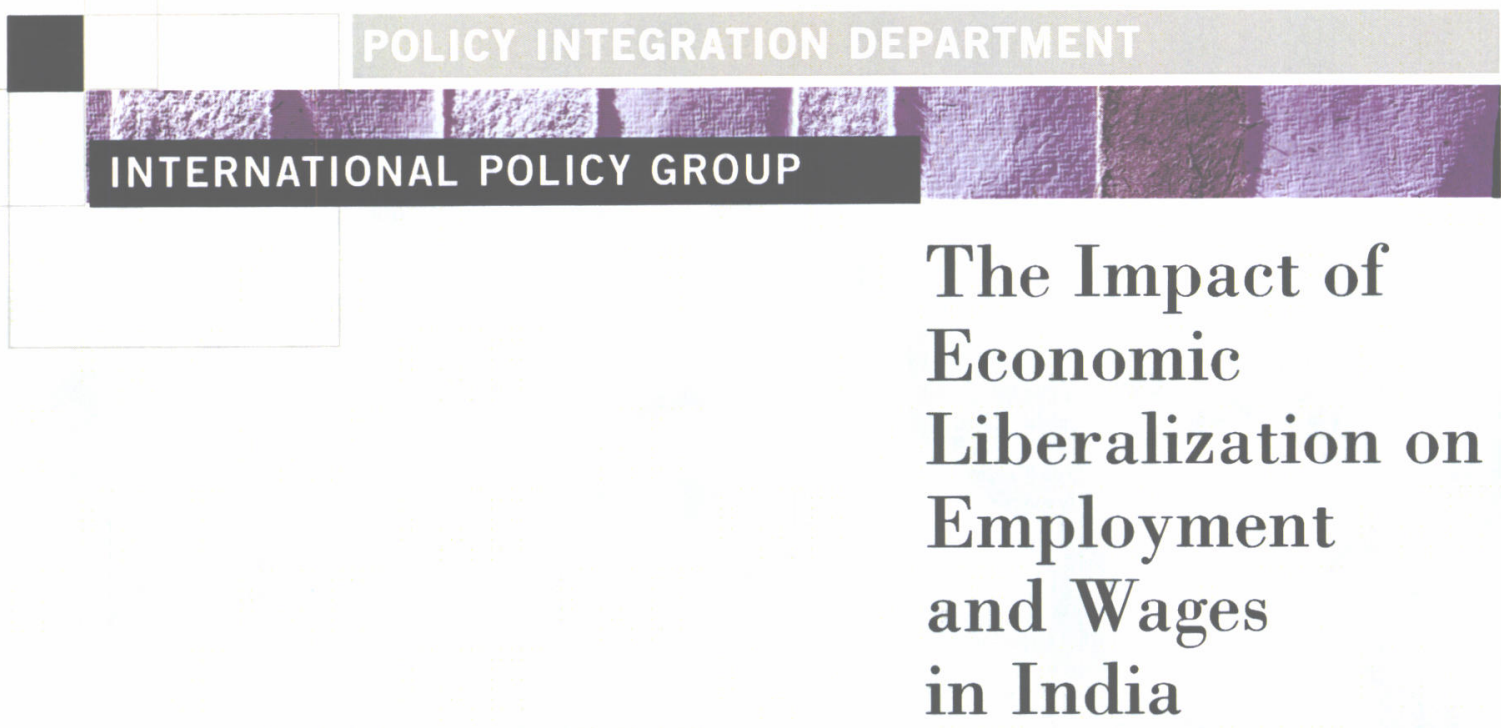

Sonia Bhalotra

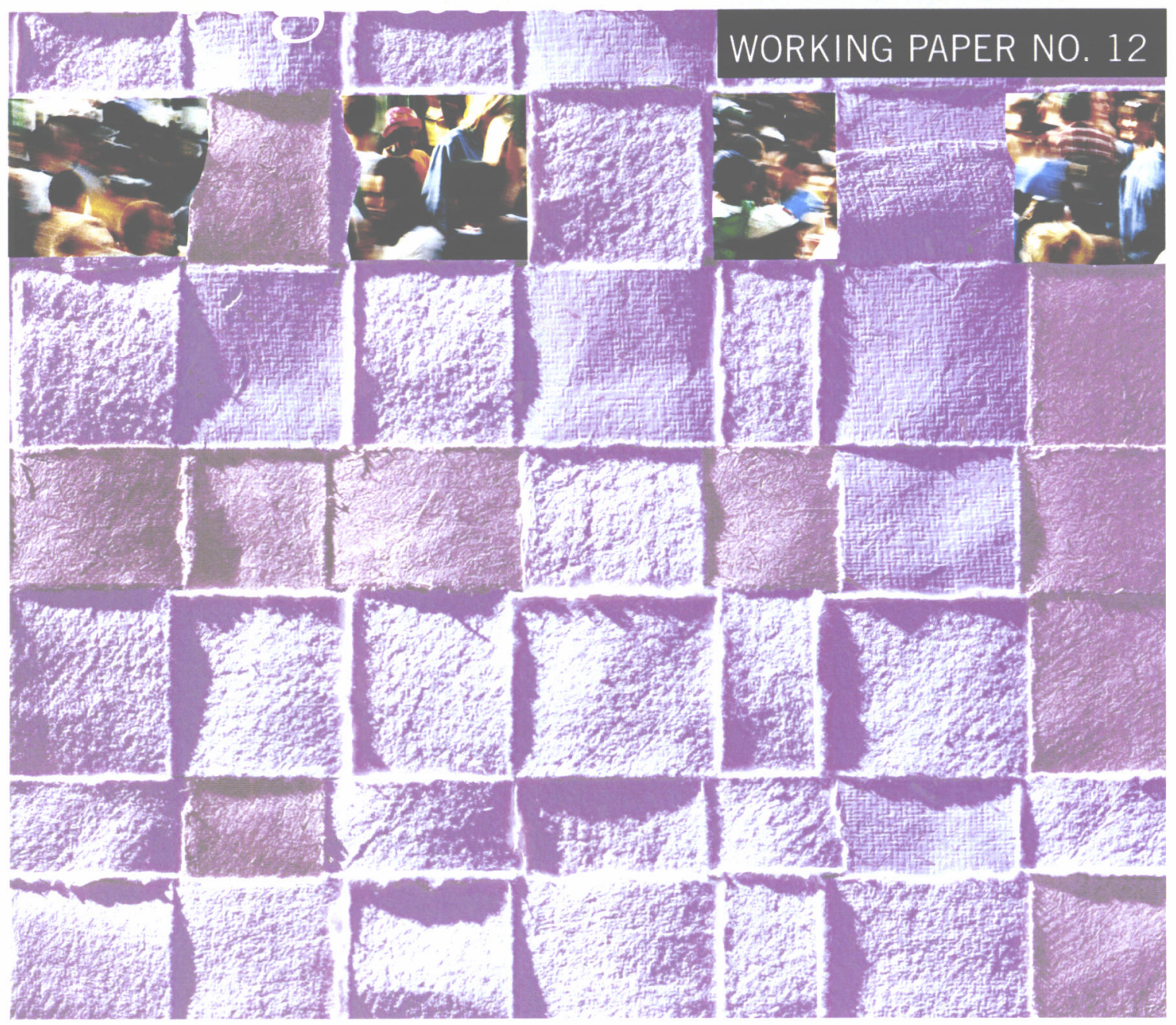




\section{The Impact of Economic Liberalization on Employment and Wages in India}

Working Paper No. 12

Sonia Bhalotra
Policy Integration Department
International Policy Group
International Labour Office
Geneva

October 2003

Working papers are preliminary documents circulated to stimulate discussion and obtain comments 
Copyright $\mathcal{C}$ International Labour Organization 2003

Publications of the International Labour Office enjoy copyright under Protocol 2 of the Universal Copyright Convention. Nevertheless, short excerpts from them may be reproduced without authorization, on condition that the source is indicated. For rights of reproduction or translation, application should be made to the ILO Publications Bureau (Rights and Permissions). International Labour Office, CH-1211 Geneva 22, Switzerland. The International Labour Office welcomes such applications.

Libraries, institutions and other users registered in the United Kingdom with the Copyright Licensing Agency, 90 Tottenham Court Road, London W1T 4LP [Fax: (+44) (0)20 7631 5500; email: cla@cla.co.uk]. in the United States with the Copyright Clearance Center, 222 Rosewood Drive. Danvers, MA 01923 [Fax: $(+1)(978) 750$ 4470: email: info 0 copyright.com] or in other countries with associated Reproduction Rights Organizations, may make photocopies in accordance with the licences issued to them for this purpose.

ISBN 92-2-113695-7

First published 2003

The designations employed in ILO publications, which are in conformity with United Nations practice, and the presentation of material therein do not imply the expression of any opinion whatsoever on the part of the International Labour Office concerning the legal status of any country, area or territory or of its authorities, or concerning the delimitation of its frontiers.

The responsibility for opinions expressed in signed articles, studies and other contributions rests solely with their authors. and publication does not constitute an endorsement by the International Labour Office of the opinions expressed in them.

Reference to names of firms and commercial products and processes does not imply their endorsement by the International Labour Office, and any failure to mention a particular firm, commercial product or process is not a sign of disapproval.

ILO publications can be obtained through major booksellers or ILO local offices in many countries, or direct from ILO Publications, International Labour Office, $\mathrm{CH}-1211$ Geneva 22, Switzerland. Catalogues or lists of new publications are available free of charge from the above address. 


\section{The Impact of Economic Liberalization on Employment and Wages in India}

\section{Contents}

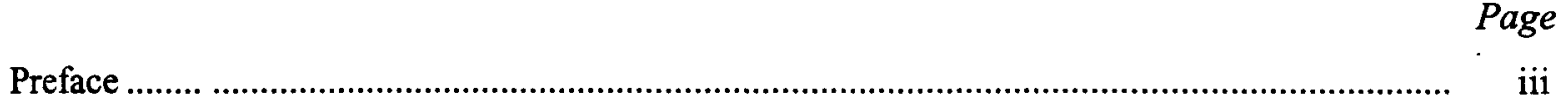

1. Introduction

2. Introducing economic liberalization ..........................................................................

2.1 What is economic liberalization? ......................................................................... 4

2.2 Overview of liberalization in India .................................................................... 4

2.3 Is liberalization "good"? ................................................................................ 5

2.4 Approaches to evaluation................................................................................ 6

2.5 The nature of the debate: an illustration.............................................................. 7

3. Employment: changes in level and structure .......................................................... 8

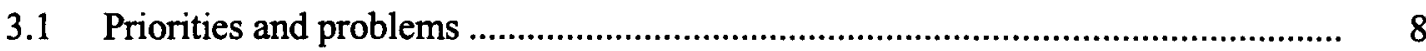

3.2 Quality of employment ……………………………………………….... 9

3.3 The role of growth in generating employment...................................................... 10

3.4 Labour laws and job security regulations........................................................ 11

3.5 Employment changes in the reform era.............................................................. 12

3.6 Employment in the 1980s............................................................................. 14

3.7 Employment in the 1990s............................................................................ 17

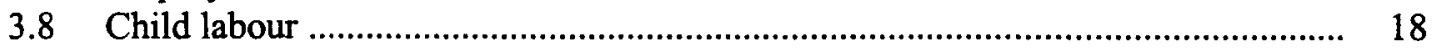

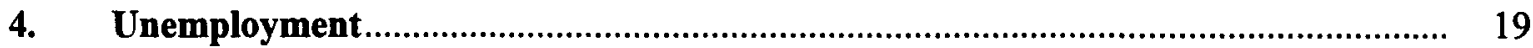

4.1 Concepts and data ......................................................................................... 19

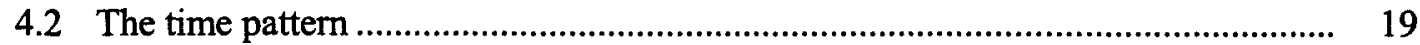

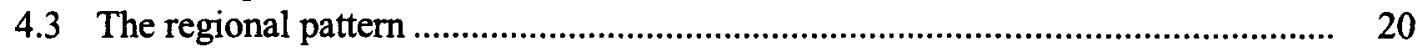

4.4 Alternative explanations of persistent unemployment rate differentials ............................................................................................ 21

4.5 Labour demand and unemployment rates ....................................................... 21

4.6 The wage-dampening effect of unemployment................................................ 22

4.7 The long-run wage-unemployment relation across regions .................................. 22

4.8 Kerala: the outlier.............................................................................................. 23

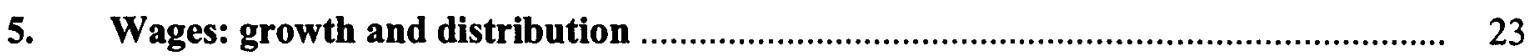

5.1 Wage growth in the reform era ..................................................................... 23

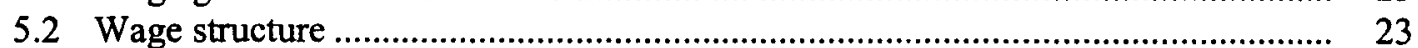

5.3 Imperfectly competitive labour markets?................................................................ 27

5.4 Wage determinants: a summary of findings........................................................ 27

5.5 Efficiency wages ......................................................................................... 29 


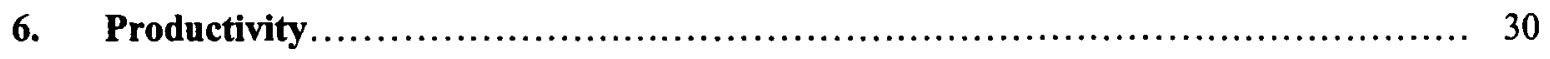

6.1 Economy-wide productivity growth............................................................ 30

6.2 Productivity growth in organized manufacturing................................................. 31

6.3 The production technology in Indian manufacturing .............................................. 31

6.4 Issues of measurement of productivity growth ..................................................... 32

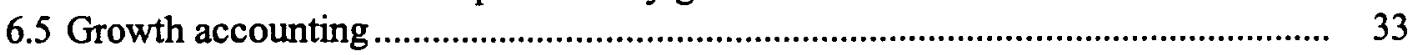

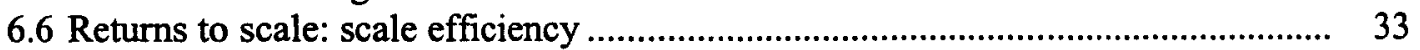

6.7 Regional productivity differentials ........................................................... 34

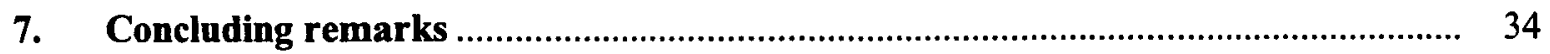

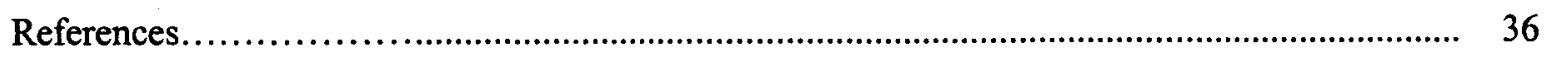

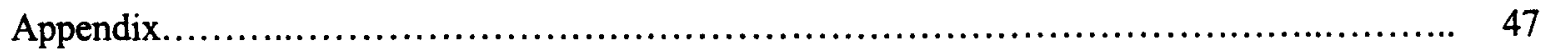




\section{Preface}

Within the Policy Integration Department, the International Policy Group (IPG) focuses on developments in the global economy and undertakes analytical work with a view to promoting the ILO's Decent Work Agenda in the formulation of international economic policy. IPG serves as the technical secretariat to the ILO Governing Body Working Party on the Social Dimension of Globalization

This working paper is an output of the first phase of a research project funded by the Department for International Development (DFID) of the United Kingdom Government, on the impact of opening to trade and foreign direct investment on employment, income distribution and poverty in developing countries. In this phase of the project the studies are based on international cross-section data. The second phase, currently underway, will consist of country studies.

In her contribution, Sonia Bhalotra critically discusses the effect of economic liberalisation - including opening to trade and foreign investment - on the Indian labour market, devoting particular attention to employment, unemployment, wages, productivity and conditions of work.

The views expressed are those of the author.

As an INTEGRATION Working Paper, this document is intended to stimulate further debate on key issues of globalization and its social dimension.

$\begin{array}{ll} & \text { Eddy Lee } \\ & \text { Director } \\ \text { September } 2003 & \text { International Policy Group } \\ & \text { Policy Integration Department }\end{array}$





\section{The Impact of Economic Liberalization on Employment and Wages in India}

\section{Introduction}

This paper assesses changes in the level and structure of employment and wages in India, relating them to trends in productivity. The discussion is set in the context of the ongoing economic reforms in India and it therefore focuses on developments through the 1980 s and 1990s relative to the previous period. In reviewing available studies of liberalization and the labour market in India, this paper argues that they suffer from a failure to recognize the importance of theory in formulating hypotheses and in offering a framework within which to cast opposing views. Opinions are often put forward without reference to the data and, where data analyses have been done, they have tended to be ad hoc, ignoring restrictions imposed by economic theory and seemingly unaware of econometric issues that can create biases. For these reasons, one has to be very careful in drawing conclusions from the available literature. We attempt in this paper to discern important features of the data and to summarize what we have learnt so far, while delineating directions (and methods) for further research. It is important to stress that it is almost impossible to ascribe causality to relations that describe changes that have occurred since the start of the reform process and to note that the reforms are still in progress.

In view of what we have said above, it would be incorrect to make bold statements about the effects of economic liberalization. However, our broad conclusions are as follows. In the economy as a whole, the worker-population ratio declined in the 1990s for men and women in rural and urban areas in most age groups in the range 5-59. Amongst the young, school participation has increased as child and youth labour have declined. Further research is needed to understand the causes and the implications of the decline in work rates amongst adults. The composition of the workforce has exhibited considerable stability overall though the share of casual workers in the total has been increasing gradually since the early 1970 s, generating the concern that the quality of employment in India is not improving. However, there was an across-the-board improvement in the growth rate of labour productivity and wages in the1980s and 1990s, and it is estimated that average per capita earnings per annum increased in that period. This is fairly remarkable, given that work participation had fallen and food prices were rising. Consistent with this, poverty incidence declined. So the poor were not entirely excluded from the changes in progress. By the most comprehensive measure available, the unemployment rate increased from 6 per cent to 7.3 per cent in the 1990s. In the absence of any analysis of the dynamics of unemployment, it is difficult to discern whether the increase denotes the frictional (and transitional) unemployment that one would expect in an adjusting economy or whether it reflects a lengthening of individual unemployment spells. 
As pre-reform regulations and restrictions were concentrated upon the registered manufacturing sector, this is the seat of reform and the place in which to expect direct effects to show ${ }^{1}$. Although still small, it is a relatively productive and growing sector which shares backward and forward linkages with the other sectors in the economy and this makes events in this sector more pertinent than its size alone would suggest. It also produces most of the good jobs in the economy and thinkers and planners have for decades looked to it to absorb "surplus labour" from agriculture and other sectors into more productive, better paid and regular employment. For all of these reasons, much of the discussion in this paper refers to this sector.

The economics of manufacturing does seem to have undergone a fundamental change since the early 1980s. There has been a distinct increase in competition and some perceptible changes in structure. Up until the late 1970s, Indian manufacturing was characterized by modest growth in value added, excess capacity in capital and surplus labour and, as a result, a high degree of inefficiency. The growth of value added has risen and a higher rate of growth has been sustained in the last two decades than was seen before 1980. In the first decade of (tentative) reform, total factor productivity displayed a fairly remarkable increase, underlying which were increases in both the utilization and the productivity of both labour and capital. This means that output growth was achieved without a very large increase in factor inputs. Indeed, employment growth collapsed during the $1980 \mathrm{~s}$, which seemed to have been a time of de-hoarding of labour and upgrading of capital stocks. This adjustment done, employment growth was restored in the 1980s and the rate of productivity increase slowed down a bit but remained significantly positive. Real earnings per worker in registered manufacturing exhibited a time pattern similar to that displayed by labour productivity, increasing rapidly in the 1980s and more slowly but positively in the 1990s. This suggests that workers were able to share in economic progress in this sector, despite indications that their bargaining power had declined. Indeed, we identify robust evidence of insider wage-setting in Indian manufacturing. This is expected to curb employment growth in the short run but, conditional on product market competition, not in the long run. In a labour-surplus economy like that of India this is important evidence in relation to the contentious issue of the spread of the benefits of growth. It is especially relevant to the question of the ways in which reforms that increase product market competition may impact on the labour market. We also find evidence of efficiency wage setting and this will tend to modify the long-run impact of wage increases on employment.

Disaggregation to the two-digit industry level shows that these trends reflected across-the-board changes rather than being driven by the idiosyncratic experience of one large sector. This suggests that the causes driving the change were common to the whole sector and a plausible candidate is economic reform. The aggregate trends conceal some changes in industrial structure. Indeed, one expects structural change and churning in the labour market as resources are reallocated in favour of relatively productive sectors. Within manufacturing, the 1990s show a dramatic and increasing shift in employment from the public to the private sector. It is very plausible that this is a direct consequence of the

\footnotetext{
${ }^{1}$ The factory or registered manufacturing sector consists of firms with at least 10 workers with power-operated machines, or 20 without. The factory sector comprises the census sector and the sample sector, the names arising from the manner in which they are surveyed in the Annual Survey of Industries (ASI). The census sector comprises the larger factories, with at least 50 workers with power or at least 100 without; smaller factories fall into the sample sector. There are no consistently available statistics on unregistered manufacturing establishments at the bottom of the size range. It is estimated that, in 1974/75, the share of the factory sector in urban manufacturing was $55 \%$ in terms of employment and $84 \%$ in terms of value added. In the same year, its employment share in total (rural plus urban) manufacturing was $28 \%$, and its value added share $74 \%$ (Sundaram and Tendulkar, 1988).
} 
reforms. The size structure of registered manufacturing has also been changing in favour of small ( $<500$ workers) establishments and this change is apparent in most of the 2-digit sectors. This tendency, however, is more complex and has been in progress since the 1950s. There appears to be no analysis of the earnings distribution within manufacturing in the $1990 \mathrm{~s}$, but research done for the $1980 \mathrm{~s}$ shows remarkable and persistent inequality along the lines of both industry and state. The invariant component of inter-industry wage inequality seems to reflect technology whereas persistent wage inequality across states is probably a result of the substantial inequalities among states in infrastructure and human capital.

The paper is laid out as follows. Section 2 defines economic liberalization and outlines approaches taken to evaluate its effects. It then briefly describes the current state of thinking on the potential and the actual consequences of liberalization. This Section is illustrative and guiding rather than comprehensive or representative. Recent evidence on the level and structure of employment is surveyed in Section 3. Timing is quite instructive here in the sense that significant changes in level and structure are noticeable as having followed the introduction of economic reforms. However, to aid a more rigorous analysis of observed changes and, thereby, predictions of the future path of employment, we discuss estimates of a model of employment determination in manufacturing. Of particular interest, we report a fairly small wage elasticity and a large output elasticity of employment, showing exactly how jobless growth or job-creating growth can come about. We argue that the Planning Commission and economists in India misleadingly refer to the inverse of labour productivity growth as the "employment elasticity of growth". In this Section we also comment on child labour and on the role of labour laws and job security. Section 4 discusses changes in the level and structure of unemployment rates in India. Although unemployment rates rose to some extent in the $1990 \mathrm{~s}$, the stability of unemployment rates and their regional dispersion is what is most striking in these data. A relevant insight that emerges from a regional model of the long-run labour market equilibrium is that, in the long run, the unemployment rate in a region is independent of labour demand (or the volume of employment) in that region. This is because regions with high labour demand have high employment but then they also attract in-migration to an extent that, in equilibrium, the unemployment rate depends only on wage push and regional amenities. This is useful in understanding the persistence in India of huge differentials in unemployment between the states. This, in turn, is an input into understanding regional inequalities in living standards. We report the effect of unemployment rates on wage rates and argue that various relevant debates rest upon the size of this parameter. The results we present suggest considerably greater wage flexibility and mobility in India's labour markets than has tended to be assumed. The growth and dispersion of wages in registered manufacturing is the subject of Section 5 . In addition to charting trends and describing the extent of wage inequality, we present an explanation of what determines wages. This offers a quantification of the magnitudes of the effects of productivity, the cost of living, unemployment rates and other variables on the evolution of wages. An interesting finding reported in this Section is that Indian employers appear to offer efficiency wages. This is relevant to understanding how employment, wages and productivity may co-evolve and it puts a completely new spin on the debate regarding the inhibiting force of protected labour markets in India. Section 6 documents the take-off in productivity growth following the onset of reforms and attempts to explain its causes. It also comments on productivity measurement, pointing to methodological flaws that corrupt many of the estimates in the literature. Concluding remarks are presented in Section 7. 


\section{Introducing economic liberalization}

India, together with about 40 other developing countries initiated its reforms in the context of a World Bank loan in the early 1980s (World Bank, 1989), before which she was a staunch import-substituter. While the pace of reform in India has been relatively slow (and, at times, unpredictable - given changes in government), it has been relatively steady - partly because it has been slow, allowing any losers in the process to adjust to the new climate.

\subsection{What is economic liberalization?}

Economic liberalization refers to both macroeconomic stabilization and microstructural change. As advocated by the IMF and the World Bank, the package of reforms typically includes some or all of the following changes: reduction in government expenditure, opening of the economy to trade and foreign investment, adjustment of the exchange rate, deregulation in most markets and the removal of restrictions on entry, on exit, on capacity and on pricing. Immediate consequences of economic liberalization that are useful to focus on are (a) an increase in internal and external competition and (b) structural change induced by changes in relative prices in the economy. Both are expected to raise efficiency. While (b) is directly related to allocative efficiency, efficiency gains associated with (a) will include technical and scale efficiency.

Of direct interest in this paper, structural adjustment includes deregulation in the labour market and measures to increase labour market flexibility. Dev (2000) remarks that "wage inflexibility and employment insecurity are the two most important aspects of labour market rigidities in many developing countries". In Section 7 on Wages, we describe in quantitative terms the inflexibility of the wage structure by industry and state and present a complete picture of wage determination in registered manufacturing. In Section 6 on Unemployment, we present an estimate of the marginal effect of unemployment on the wage, a measure of how flexible the wage is in India to market forces. In Section 5 on Employment, a subsection is dedicated to discussing the evidence on the effects of employment security on labour market outcomes.

It should be recognized that macro-stabilization and structural change, which together constitute "the economic reforms" may conflict with one another and may produce competing effects. While studying the effects of liberalization on labour market outcomes, we should also recognize that the pace of liberalization will be affected by the structure and performance of the labour market.

\subsection{Overview of liberalisation in India}

This paper is primarily concerned with the labour market effects of liberalization. Here, we briefly remark on changes in growth and trade seen in the 1980s and 1990s. Growth has accelerated, showing a significantly higher mean and greater variance since the introduction of reforms. Since 1985, imports have increased by 19 per cent and exports by 71 per cent. These denote larger increases than seen in Pakistan and Sri Lanka but smaller increases than seen in Bangladesh and Nepal, all of whom introduced broadly similar changes at a roughly similar time (see Dev 2000, p.47, for example). In 1997, exports were 12 per cent of GDP as compared with 7 per cent in 1980. Trade as a percentage of GDP rose from 17 per cent to 27 per cent in the same period. The pre-reform regime has been described as biased against agriculture, consistent with which the terms of trade have moved in favour of agriculture, and this has attracted increased private investment into this sector, especially since the late 1980s (Dev 2000). However, the average growth rate over 
all crops was much lower during the period from 1991/92 to 1995/96 than in the pre-reform period (Misra 1998). This indicates that getting prices right is not enough but that nonprice factors need to encourage growth at the same time (Dev 2000).

\subsection{Is liberalization "good"?}

\section{Available surveys}

An account of labour-protective state machinery can be found in the World Bank (1989) and a description of mechanisms for industrial protection in Bhagwati and Desai (1970). Since there is a vast literature consisting of accounts of what may or may not happen as a result of economic liberalization, this paper does not survey this area. Instead, it provides just as much analysis in this Section as is needed to provide an intelligent backdrop to the discussion of labour market outcomes that is to follow.

\section{Winners \& losers, uncertainty}

The conventional wisdom is that globalization and free markets expand opportunities and are good for workers in rich and poor countries alike (e.g. World Bank 1995). However, there is plenty of evidence to the contrary. For example, Ghose (1995) describes a reduction in the quantity and the quality of employment following structural adjustment and changes aiming to increase flexibility in African and Latin American countries. In general, there will be some losers and some winners, and there is typically no clear mechanism by which the winners are committed to compensating the losers to induce them to participate in the process of change. So, statements about what is good refer to an average and while this is an interesting summary statistic, the degree of variance around it is likely to influence perceptions of whether the instituted changes are for the better or not. If, as argued by Lee (1996), the losses are concentrated in certain areas or groups while the gains are more widely diffused and therefore less apparent, then the perception may be more negative than otherwise. Any statement about expected gains is also limited by the fact that the consequences of change are inherently uncertain. Uncertainty imposes real costs, having been shown (by economists) to have influences on key variables such as migration, investment and inflation.

\section{Ambiguity in the effects of trade liberalization}

While the reforms involve at least as much internal deregulation as opening up to trade, it is useful to illustrate the ambiguity surrounding expected effects of reform with reference to a particular change like trade. Since 1991, trade policy in India has undergone major revisions. Convertibility on the current account is now in force. The import licensing system has been dismantled. All non-tariff barriers to imports (other than consumer goods) have been phased out. Tariff rates have fallen from a maximum of 355 per cent to 50 per cent and the tariff on capital goods is close to zero.

Developments in industrial organization theory and its incorporation within trade theory, starting in the 1980s (see Helpman and Krugman 1985, 1989), have made it possible to analyse trade reform in the context of imperfect competition, allowing us to ask again the old question of what the consequences of trade reform are likely to be in developing countries but now taking account of the imperfect market economies that characterize them. A hallmark of imperfect competition is that prices exceed marginal costs of production (the latter being defined to include all relevant opportunity costs). A 
relaxation of trade restrictions in an imperfectly competitive economy can affect welfare in any of four ways (see Rodrik 1992): (a) by raising the volume of trade [increase in imports as effective import price falls], (b) through the excess profits effect [expansion in sectoral output in sectors which had super-normal profits], (c) through the scale efficiency effect [expansion in firm output in sectors with unexploited scale economies] and (d) through the technical efficiency effect [increase in productivity at the firm level]. Rodrik argues that, in the reality that most developing countries start out in, forces (b) and (c) may conflict with force (a), making it unclear whether the import-competing (formerly protected) sectors see an increase in output or not. In particular, liberalization can result in an expansion of import-competing sectors under imperfect competition, an outcome that would be most unlikely under perfect competition. In this case, the benefits of import liberalization are enhanced by the presence of imperfect competition.

Introducing imperfectly competitive markets, issues of policy credibility, and questions of the speed of reform can all be shown to result in a large degree of indeterminacy with respect to the success of the reform. For the case of policy credibility, see Rodrik (1992), who shows that trade reforms that lack credibility may be unsustainable. He shows how a relatively small degree of uncertainty regarding the progress of reform can result in a furthering of macroeconomic instability and how, at the same time, the delay in economic restructuring can block the emergence of new political alliances in favour of reform. The economy can then support multiple equilibria, of which one may be a bad equilibrium with low investment and a high probability that the reform process will collapse, with another possible equilibrium looking good and sustainable. Which equilibrium a particular reforming economy ends up in would seem to depend upon imponderables. Good indicators include policy consistency, uniformity (for example, in tariff schedules) and any mechanisms that governments may evolve to signal commitment. Overall, the earlier optimism regarding the potential of trade liberalization has been toned down and this is summarized in Rodrik (1992, p.90):

Governments that understand the limited (and possibly unconventional) role to be played by trade reform are likely to make the most of it; governments that pin on it their hopes for future growth and development are likely to be disappointed.

\subsection{Approaches to evaluation}

Analyses of the effects of this package of reforms may be thought of in at least three different ways. First, a computable general equilibrium (CGE) framework may be used, which allows for interactions between different markets and which permits simulation of counter-factuals. This gain comes at the cost of making some possibly untenable assumptions. Pradhan and Sahoo (1998) have estimated a CGE model for India which produces the following tentative results. A reduction in taxes on the production and import of capital is not welfare-increasing for households, especially not for rural households. A reduction in import duties does not seem to yield growth and welfare gains at once. Tax concessions to certain sectors, subsidies for food grains, and human capital formation increase both growth and welfare, although "excessive" expenditure on human capital or on subsidies leads to a decline in household welfare. A second approach, which is the most commonly used, is to address the question of the effects of economic reform by attributing any changes since the early 1980 s to the reforms, which is clearly dubious. There is no controlled experiment here; and there is, strictly, no "before" and "after" to the "treatment" in effect as the reforms are still in progress.

In this paper, we adopt a third approach, which represents the middle-ground between the highly structured rigid framework of CGE and the more speculative approach that most available studies have taken. We argue that economic theory can be used to construct welldefined (and falsifiable) hypotheses that capture the likely effects of liberalization on the object of interest. These hypotheses can then be investigated using appropriate 
econometric techniques on appropriate data. In the current context, economic theory is necessary to understand the structural relations determining some of the key variables (employment, wages rates, productivity, unemployment), and how they hang together. These variables are in fact jointly determined by technology, prices and market structure. Macro-stabilization and structural change introduced in recent policy reforms will tend to alter the range of technologies available, change relative prices, and move market structure in the direction of greater competition. This is a useful way in which to conceptualize the discussion to follow.

\subsection{The nature of the debate: an illustration}

The following argument illustrates the weakness of the current state of debate. It is chosen for two reasons. First, there is the pragmatic convenience that two authors have recently had an explicit debate (published in the Economic and Political Weekly) over interpretation of the data. Second, the issue under debate concerns the evolution of the size structure of manufacturing, which is interesting in a number of ways. Size is measured as employment per factory and is therefore directly related to the level and structure of employment. A less acknowledged fact is that, after holding constant productivity and other relevant variables, size has a significant positive effect on wages. This is an empirical regularity observed in micro-data for numerous countries (see Brown and Medoff 1989) and India is no exception (see Section 5.4 below). And, as the discussion to follow makes clear, changes in size structure are a possible index of the extent of restructuring induced by the reforms.

In an attempt to explain the recovery of employment growth in the 1990s, Goldar (2000) argues that the shift in size structure in favour of smaller units is a result of economic liberalization. Nagaraj (2000) has disputed this claim on the grounds that the shift is part of a continuing trend that started in the 1950s. In fact Goldar's claim may hold despite Nagaraj's observation if size-changes were more rapid or more extensive in the 1990 s than in previous decades and so the argument remains open. Here we are making the point that resolving a debate can depend upon quantification.

This debate also illustrates that it is tempting to attribute to economic liberalization any properties that seem to fit with the data. Thus Goldar argues that a shift towards smaller size is consistent with economic reform doing away with protection, investment incentives, credit control and the promotion of industry in the public sector (he refers to Little 1986, p.230). Nagaraj, on the other hand, notes an investment boom in the 1990s and argues that this may be a response to deregulation in industry and trade. He is implicitly supporting the view that the Monopoly and Restrictive Trade Practices Act (MRTP) and reservations (positive discrimination) in favour of "the small sector" restricted firms from expanding to their optimal size (e.g. Fikkert and Hasan, 1998). These represent conflicting views of what the pre-reform regulations did: did they make firms "too small" or "too large"? In fact, both views are misleading. The only correct way to address this question is to see the pre-reform restrictions on economic activity as preventing firms from achieving their optimal size. The optimal size of a firm depends upon technology and market size, and will be different in different industries. Under what conditions, then, would we expect the reforms to result in an overall shift towards smaller-sized establishments? Either firms in every industry would have to have been larger than is optimal before the reforms, or industrial composition would have to have changed during the reform period with demand growing more quickly for the products of industries in which optimal firm size is relatively small. Research aiming to understand size structure in the context of reform should investigate these empirical predictions. The observed size structure may reflect both tendencies, with some firms entering the reform era larger than efficient and becoming lean and fit under the force of competition, and with others entering with unexploited potential and realising this by virtue of unrestricted expansion in the reform era. In principle, therefore, moving towards optimal size may involve some firms growing smaller 
and others growing larger. An understanding of what exactly was going on is confounded by the fact that the recorded changes in size structure denote snapshots of an inherently dynamic process and one that we have no reason to believe is in equilibrium.

\section{Employment: changes in level and structure}

\subsection{Priorities and problems}

The introductory paragraph of the recent Report of the Task Force on Employment Opportunities (Planning Commission, 2001), commissioned by the Government of India is as follows:

The need to ensure adequate growth in employment opportunities to provide productive employment for the continuing increase in the labour force is widely regarded as one of the most important problems facing the country. There is widespread concern that the acceleration in GDP growth in the post-reform period has not been accompanied by a commensurate expansion in employment. Public sector employment is expected to fall as the public sector withdraws from many areas. There are fears that the processes of internal liberalization and globalization, inevitable though they may be, are creating an environment which is not conducive to expanding employment in the organized private sector. Existing industrial units are shedding excess labour in order to remain competitive, and new technology, which is essential to ensure competitiveness, is typically more automated and therefore not job-creating. The net result of these forces, it is feared, could be a very slow expansion in employment opportunities in the organized sector, with a rise in unemployment rates and growing frustration among the youth. The problem is perceived to be especially severe for educated youth, who have high expectations about the quality of employment opportunities that should come their way (para.1.1).

This paper will discuss all of the concerns expressed in this paragraph. This paragraph takes up some the specific claims made in the preceding paragraph, some of which are valid but some of which are not supported by the evidence. Following a severe decline in the 1980 s, employment growth in the organized manufacturing sector picked up to a healthy level in the 1990s (e.g. Goldar 2000, Nagaraj 2000). The comment in the Report refers to average growth during 1983-94, which was only 1.2 per cent p.a. While there does appear to have been some shedding of excess labour which contributed to the collapse of employment growth for 4-5 years in the 1980s, it appears that, upon becoming lean and fit, firms have been able to compete and grow (see Bhalotra 1998b). The evidence on changes in technology is limited except for case studies of particular industries (e.g. Howell and Kambhampati 1999). Although, as expected, public sector employment has not grown in the 1990s, a healthy growth rate in employment in the registered private sector has made up for that (see Goldar 2000). The concern expressed in the Report that liberalization is not conducive to organized sector employment growth is therefore not borne out by the data. However, looking at the whole economy rather than the organized sector alone, employment growth does appear to have slowed (from 2 per cent p.a. in the 1983-1993/94 period to less than 1 per cent p.a. during the period from 1993/94 to 1999/2000: Planning Commission, 2001). This appears to largely reflect a similar slowdown in the growth rate of the labour force. Nevertheless, overall unemployment rates have risen, from 6 per cent in 1993/94 to 7.3 per cent in 1999/2000. However, unemployment rates for the educated have fallen, so that is not the overarching concern (see Sundaram 2001, for example, who uses NSS data). The issue of quality of employment is, however, a key issue, and is discussed separately below. 


\subsection{Quality of employment}

\section{Aspects of job quality}

The vast majority of Indian workers are employed in the informal or unorganized sector where jobs are unprotected and uncertain and labour market competition keeps wages low. Since strict unemployment is a luxury in the absence of state-provided unemployment benefits, the poor are forced to work but there is a high degree of underemployment in terms of irregular days of work and low incomes. The NSS estimates that about 7.3 per cent of India's labour force was either chronically unemployed or underemployed in 1999/2000. A further 33 per cent of workers were in casual employment, where earnings are considerably smaller than in regular employment and expected earnings smaller still. ${ }^{2}$ Casual workers also experience income uncertainty, which imposes particularly large welfare costs on the poor as negative income shocks make them vulnerable to death, illness and poverty traps. Volatile incomes characterize, but are not exclusive to agriculture, which engages about 60 per cent of the workforce. A healthy supply of organized sector jobs which are regular and relatively well-paid takes on immense significance in India.

\section{Changes in quality of employment}

Turning to changes over time, the unemployment rate fell between 1983 and $1987 / 88$ by a substantial 2.3 percentage points and remained stable until 1993/94. In the six years to $1999 / 2000$, it registered a 1 percentage point increase. The proportion of casual workers in the labour force has been increasing continuously through the last three decades, apparently no more quickly in the wake of economic reforms than before (see the data in Minhas and Majumdar 1987, Vaidyanathan 1994, Sundaram 2001). In line with the share of casual workers rising from 27 per cent in 1977/78 to 33 per cent in 1999/2000, the share of self-employment has fallen continuously from 59 per cent in $1977 / 78$ to 53 per cent in $1999 / 2000$. There has been a noticeable shift of workers from rural non-farm employment to agriculture (see Bhalla 1997) which has been attributed to declining public expenditure in the reform period (Sen 1996). The share in regular employment has remained around 14 per cent. It has to be said that both unemployment and the structure of the labour force have exhibited a great deal of stability, the changes we report being rather small (see Tables 2.4, 2.30 Planning Commission 2001). Thus, by the criterion of unemployment and of employment rates in regular jobs, there is no very compelling evidence that the quality of employment has improved in the course of economic liberalization, though there has been no dramatic worsening. Concomitant with an across-the-board rise in labour productivity in the 1990s, the average yearly wage earnings of (usual-status) casual workers have increased at about 3.6 per cent p.a. in real terms during the 1993/94$1999 / 2000$ period. Consumer expenditure data for the same period show a decline in both rural and urban poverty in this period (Sundaram 2001). By this criterion, there is some evidence of an improvement in the quality of employment in the wake of economic reform.

\section{Policy interventions}

What can be done to ensure larger and sustained increases in employment quality in India? Rather than expect growth to deliver jobs through restriction of choice of optimal

${ }^{2}$ In 1990 , the daily wage of a casual worker was, on average, 0.4 times that in regular employment (Sarvekshana 1990, Tables 79 and 81U). 
technologies (or other restrictions), investments in education and training of the work force should be made and these will deliver increases in labour productivity, quality employment and higher rates of sustainable economic growth.

In 1999-2000, 44 per cent of the labour force was illiterate and only 33 per cent had schooling up to or above the secondary level. Only 5 per cent of 20-24 year-olds in India's labour force had vocational skills compared, for instance, to 28 per cent in Mexico and 96 per cent in Korea! (Planning Commission 2001). Although school enrolment rates have been on the rise, they need to rise more rapidly. The Task Force Report cited above recognizes human capital investment as one of five ways of using policy to encourage both the quantity and the quality of employment. The other four areas of potential policy action that it identifies are as follows. First, it suggests finding policies that encourage growth of GDP with an emphasis on sectors likely to ensure the spread of income to the low-income segments of the labour force. Second, pursuit of sectoral (and regional) policies consistent with acceleration of GDP (for example, investment in agricultural infrastructure, especially in the poorer states). Third, special programmes for employment and income generation amongst vulnerable groups. Fourth, ensuring that the policy and legal environment governing the labour market encourages labour absorption, especially in the organized sector. We will now elaborate on the role of growth and on the regulatory framework in the labour market, but we do not discuss sectoral policies or special programmes for employment generation, an overview of which is given in the Task Force report (Planning Commission 2001, Chapters 4 \& 5).

\subsection{The role of growth in generating employment}

The Planning Commission (2001) argues that the role of GDP growth in achieving India's employment objectives is overwhelming. They conduct growth simulations using several arguable assumptions. One such assumption that is particularly worthy of attention as it is made in numerous micro and macro studies of the Indian economy is that the output elasticity of employment is the ratio of past changes in employment to past changes in output. This is incorrect. In fact this is simply the inverse of the change in labour productivity. The correct elasticity is the marginal effect of output on employment, conditional on real wage rates and an index of technical progress (see Appendix 1 for models of employment). A well-specified model of employment determination is estimated by Generalized Method of Moments (GMM) methods applied to a panel of industry-state data for the 1979-87 period (see Bhalotra 1998a). This gives a long-run elasticity of income that is just larger than 1 and a short-run elasticity of 0.41 . So, in the long run, for given wage rates and days of work, a 5 per cent increase in output is expected to generate a 5 per cent increase in employment. But how long is the long run here? The speed of employment adjustment is estimated in the same paper to be 0.33 (s.e. $=0.072$ ). It takes 1.7 years to complete half the adjustment and 5.8 years to complete 90 per cent of the desired adjustment. ${ }^{3}$

It is important to recognize that raising labour productivity is a way of creating highquality employment. The often-heard rhetoric that growth is not being accompanied by adequate employment neglects this: if employment grew as rapidly as output then that would imply no growth in labour productivity. Even in a labour-surplus economy, this is undesirable. The real question here is how productivity gains are distributed. To the extent

\footnotetext{
${ }^{3}$ Directly comparable Planning Commission estimates of employment elasticity are not available as their periodization is different and their estimates refer to all manufacturing (based on the NSS) rather than to registered manufacturing (based on the ASI). However, the concern expressed about liberalization curbing employment growth suggests that they would put the elasticity of employment at less than unity.
} 
that they are shared with incumbent workers as wage premia, employment will tend to be lower than otherwise. Introducing the possibility of efficiency wages would further complicate this analysis (see Section 7). As discussed above, investments in human capital - in India, especially widening basic education - will yield both growth and wider participation in the benefits of growth.

\subsection{Labour laws and job security regulations}

A commonly held opinion is that policy-induced rigidities in the industrial labour market contributed significantly to the poor performance of Indian manufacturing up until the early 1980s (e.g. Lucas 1988, Datt-Chaudhuri 1995). More recently, the Planning Commission (2001) devotes an entire chapter to arguing that labour market rigidities may have interfered with adjustment to the more competitive environment created by economic reform (see para.1.3 for example). It argues that India's labour laws have discouraged investment in and expansion of labour-intensive sectors and have made India uncompetitive in export markets (para.1.12). On the other hand, there are concerns that economic liberalization will result in the "erosion of many institutions for labour welfare" (e.g. Dev 2000, p.42). Overall, in a poor country, job protection can be an important form of social security provision but the possibility that it costs jobs makes it controversial. This is a sensitive issue, and the Planning Commission (2001) suggests parallel reform of the bankruptcy law and creation of unemployment insurance based on contributions from employers and workers. A comprehensive review of labour laws is soon to be undertaken by the Second Labour Commission.

An area that is thought to need urgent review (see Planning Commission 2001, para.1.1) is job security provision, which is the requirement that firms seek government permission for retrenchment and closure. This is assumed to lead to more capital-intensive technologies and/or the contracting-out of work to smaller enterprises that lie outside the scope of these regulations. The law was introduced in 1976, to apply to firms with at least 300 employees. In 1982, it was extended to establishments with at least 100 employees, encompassing approximately an additional 15 per cent of workers. It was in 1982 that employment growth turned negative, and a popular view is that this was associated with the extended scope of job protection (e.g. Government of India, 1993, p.34). Of course this already looks less plausible an argument given that employment in the 1990s recovered without any significant relaxation of the law. Fallon and Lucas (1993) estimate that employment in organized manufacturing would have been 17.5 per cent higher (in the 1970 s and 1980s) if there had been no job security provision. However, in a more convincing econometric analysis of inter-related factor demands, Dutta-Roy (1998) rejects the hypothesis that job security has a significant impact on labour demand. Other authors who have expressed scepticism about the importance of job security are Papola (1994) and Ghose (1994).

The argument that concerns about job security is not very persuasive rests upon the following reasons (drawn from Bhalotra 1998a). First, it takes time to adjust employment and so the coincidence in time of the amendment and the fall in employment cannot be very significant. It is estimated that it takes almost 6 years in Indian factories for 90 per cent of the adjustment in employment to its optimal level to be completed (Bhalotra 1998a). Second, various micro-level studies have found considerable evasion of the law (e.g. Mathur 1989, Deshpande 1992, Papola 1992). Third, the finding that regional unemployment exerts downward pressure on manufacturing wages (Bhalotra 1996) also argues against the view that job security is binding because workers that face no threat of layoff may be expected to be entirely insulated from market pressures. Fourth, since job protection lowers hiring and firing rates, its direct impact on employment is, a priori, just as likely to be positive as negative and, indeed, investigations of job protection in the OECD are inconclusive about its impact on labour demand (Layard, Nickell and Jackman, 
1991 , p. 502). Fifth, if the extension of job security had bite, we would have expected to observe threshold effects at 100 workers. Instead, employment growth was positive in factories with less than 1000 workers and negative in larger ones (Nagaraj, 1994). Finally, recent evidence also appears to deny the view that there are prohibitive restrictions on firing. As discussed above, there were layoffs in the 1980s, insider pressure was not able to maintain employment growth and, in the 1990s, public sector employment ceased to grow.

This is not to say that the introduction of job security has left no mark at all. Job security probably nurtures wage push, with consequences for employment that are captured by the wage elasticity. Further, to the extent that job security raises the costs of employment adjustment, it will give rise to employment dynamics (of which evidence is presented in Bhalotra 1998a and Dutta-Roy 1998).

Having argued that job security is probably not as hampering of growth and employment as depicted, it must be said that the view from the opposite camp is not any more defensible. This is the idea that job security and related provisions for registered sector workers must be imposed by the government in order to avoid casualization of the labour force and an overall deterioration of the quality of employment. This view neglects to recognize that it may well be in the interest of private employers to offer higher quality employment. This may be necessary to enable effort, to recruit and retain workers, or else to motivate them (see Section 5.5). A casual low-cost workforce does not necessarily raise firm profits as worker quality and effort become difficult to guarantee. Our broad view is hence that the labour laws in India do not do much harm but that they probably do not do much good either.

\subsection{Employment changes in the reform era}

\subsubsection{Employment in all sectors}

Using NSS data from the Employment-Unemployment Survey which is representative of the country and inclusive of the organized and unorganized sectors, Sundaram (2001) finds a decline in the crude worker-population ratio for men and women in rural and urban areas and in all of the age groups in the 5-59 year range. In absolute terms, the number of women workers in rural areas declined but this was offset by a rise in the number of women workers in urban areas. The decline in child and youth work participation was reflected in a rise in school enrolment at the primary and higher levels. There were some changes in the structure of the economy: a decline in the share of the population engaged in agriculture and a small rise in the share engaged in manufacturing, the more substantial increases being in trade, hotels and restaurants; construction; and transport, communications and storage.

\begin{tabular}{l|r|r|r|r}
\hline \multicolumn{5}{c}{ Relative size and productivity of Indian manufacturing } \\
\hline & India & & UK & \\
Manufacturing statistics & 1951 & 1991 & 1960 & 1991 \\
$\%$ GDP & 10 & 33 & 37 & 22 \\
$\%$ Employment & 11 & 16 & 37 & 23 \\
& & & & \\
\hline
\end{tabular}




\subsubsection{Employment in registered manufacturing}

Employment in the organized manufacturing sector grew fairly rapidly up until the decade of the 1980s, when it stopped growing. In the 1990s, the growth rate climbed back. Economic reforms were introduced somewhat tentatively from about the start of the 1980s, gaining strength and momentum only after 1991. The evidence is therefore that employment growth in this sector collapsed for the first six to seven years of the liberalising regime, since which time it has returned to more or less its former level on average, exhibiting more fluctuation than before.

In the 1970 s, employment growth averaged 3.8 per cent while output was growing at the fairly conservative rate of 4.5 per cent. In the 1980-1990 period, employment growth dropped to 0.53 per cent p.a. while value added grew more rapidly, at 8.7 per cent p.a. In the following decade (1990-1997), output growth slowed a bit to 7.4 per cent p.a. but employment growth recovered to a rate of 2.7 per cent p.a. (in fact 4 per cent p.a. in the period from 1990/1 to 1995/6). Trend growth in the 1987-1998 period was about 3.2 per cent p.a. and there appears to be no structural break around 1991/92 (see Nagaraj 2000, Goldar 2000). The collapse in employment growth from the 1970s to the 1980 s was observed across most 2-digit sectors (Nagaraj 1994, Bhalotra 1995, Chapter 4) and, similarly, the growth in employment from the 1980s to the 1990s was seen in most 2-digit sectors (Goldar, 2000). Thus it does not seem that the fortunes of a particular sector were driving these trends, making it useful to seek an explanation of them in terms of overall events in the manufacturing sector.

Employment growth in the 1990s was almost entirely in the private (and joint) sector (see below and table 1). Looking at trends with the public and private sectors differentiated is very revealing. In the 1970 s, employment growth was rapid in both sectors, and in the 1980 s it collapsed in both sectors. In both decades, however, the rate of employment growth was higher in the public than in the private sector. The 1990s mark a dramatic change. Employment in the public sector grew even more slowly than in the 1980s, while private sector employment grew rapidly, at a rate comparable to that in the 1970 s.

The aggregate data raise three questions. First, why did employment cease to grow in the early years of the transition? How growth was restored and is it likely to grow at a similar and stable rate from now onwards? Second, do the similar growth rates of employment before and after the 1980s conceal changes in the composition of employment? How much structural change have the reforms induced? Has the quality of employment improved or deteriorated? Third, has the employment function changed? Have the reforms been associated with changes in technology, or in expectations that are reflected in the output and wage elasticities of employment? The rest of this Section discusses the available information on these questions, indicating where further research is required.

Table 1: Employment growth in organised industry: public versus private sector

\begin{tabular}{lccr}
\hline & $1973-80$ & $1980-90$ & $1990-97$ \\
\hline Public sector & 5.97 & 1.27 & 0.39 \\
Private \& joint sector & 3.50 & 0.30 & 3.72 \\
Aggregate ASl" & 4.11 & 0.57 & 2.83 \\
Notes: Figures are growth rates in percentage per annum. Data for manufacturing alone are not available so these figures include \\
electricity, gas, etc. The joint sector refers to public-private partnership. \\
"The ASI is the Annual Survey of Industries published by the Central Statistical Office in New Delhi. \\
Source: Goldar (2000), based on aggregate ASl publications
\end{tabular}


While the growth in output and productivity in the 1980 s was interpreted as the reward of deregulation (e.g. Ahluwalia, 1991), job losses in manufacturing $(200,000$ workers in the 1982-1986 period, when employment actually declined) generated scepticism about the economic reforms (e.g. Datt 1993, Mundle 1992) ${ }^{4}$ Employment is a central concern in India and it has fuelled some of the political resistance to reform. Despite the recovery in the 1990s, there remains scepticism regarding allocation of the benefits of growth (e.g. Planning Commission 2001).

More generally, the implications of economic reform for employment growth have attracted a great deal of discussion (and speculation) amongst Indian economists and policy makers. Most have been pessimistic (Mundle 1992, 1993; Deshpande 1992; Bhattacharya and Mitra 1993; Mitra 1993; Agarwal and Goldar 1995; Kundu 1997). For example, Ghose (1994) has argued that increased competition will induce firms to slim their workforces while, at the same time, improved access to foreign technology and capital goods, both associated with the reforms, will tend to increase the capital intensity of production. Some, however, have argued that economic reform will be associated with greater labour market flexibility and with a shift towards labour intensive techniques and industries in response to an increased openness to trade (Singh (1993), Papola (1994)). Others have anticipated labour market adjustments in the wake of reform and predicted in advance of the evidence that employment growth would be restored after a short adjustment period (see Bhalotra 1995, Chapter 4, Bhalotra 1998a), Nagaraj (1994), Srivastava (1996). Many of the studies cited contain opinions rather than the predictions of rigorous analysis. Also, as discussed earlier, it is inherently difficult to arrive at strong conclusions about the impact of the economic reforms as (a) they are not a controlled experiment and there is no available counter-factual, (b) the reforms are still in progress and some of the adjustments to reform may still be working themselves out, and (c) they are a package of changes, different parts of which may have very different effects on the object of interest (employment in this case).

\subsection{Employment in the 1980s}

Capital and output were growing rapidly in the 1980 s and this alone would lead us to expect healthy employment growth. Instead, several industries had negative growth in employment and, in manufacturing as a whole, employment growth was insignificantly different from zero. The collapse of employment in the 1980s has stimulated research. To summarize, there are two apparently competing arguments. One is that it was a response to more rapidly growing wages in the 1980s (see World Bank 1989, Ahluwalia 1991, Ghose 1994). These authors mistakenly refer to earnings (wage rates per day multiplied by days worked) as wages. The other view disentangles wage rates from the time intensity of work to argue that, although earnings rose fairly rapidly in that decade, there was a significant increase in days worked per worker so that wage rates grew less rapidly than earnings (see Nagaraj 1994, Bhalotra 1995, Chapter 4, and Papola 1994, for a related argument).

In fact, as discussed earlier, productivity, wage rates, days worked and employment are simultaneously determined. So the preceding discussion, while highlighting important issues, does not establish what the driving forces were or how they might derive from exogenous forces such as economic reform. Economic theory offers a systematic way of organising the relationships between these variables and, combined with sound econometrics, allows the researcher to make (conditional) causal statements. Using a panel

${ }^{4}$ The following, from Datt (1993), illustrates a popular sentiment in India: 'An overall assessment of NEP [the new economic policy] suggests that the interests of labour would be sacrificed at the altar of the interest of big business - both Indian and foreign', or '..World Bank and IMF are emphasizing a lesser and lesser role for the Government, leaving the poor and the unemployed in the cold and indifferent hands of market forces'. 
of industry-region data for the 1979-1987 period, during which employment growth averaged -0.3 per cent p.a., Bhalotra (1995) estimates dynamic panel data models for wages, productivity, employment, days worked, and unemployment in an attempt to establish the underlying structural relationships, allowing for imperfectly competitive markets.

Estimates of the employment function can be used to fully account for the decline in employment. ${ }^{5}$ The short-run wage elasticity of employment is estimated to be -0.15 and this operates with a lag of a year. ${ }^{6}$ Given employment dynamics, this implies a long-run elasticity of -0.26 . Trend wage growth of 4.2 per cent p.a. during the 1979-1987 period therefore implies a decline in employment of 1.1 per cent p.a. ceteris paribus. The rival estimate in the literature implies a 5.7 per cent decline in employment on account of wage growth (see World Bank 1989, p.110). The conceptual and estimation errors that corrupt the Bank's estimate are detailed in Bhalotra (1998a). These are the results of estimating an output-constant model. For reasons discussed in Appendix 1, we prefer estimates of a capital-constant model. A full account of employment variation is now provided based upon this specification. See table 2, which reports the long-run elasticities of the main explanatory variables, their growth rate and, hence, their contribution to explaining employment change. Capital accumulation is found to exert a strong positive effect on employment. In the output-constant model, output similarly exerts a close-to-proportional increasing effect on employment. The growth in wage rates and in work intensity are found to exert a significant negative impact on employment, the largest drag on employment being associated with efficiency and other changes in the environment that were common across industries and regions. The sum of these effects produces a growth rate in employment close to that actually observed, so the puzzle of jobless growth is resolved.

Table 2: Accounting for the rate of employment growth in the 1980s

\begin{tabular}{lrrr}
\hline & Long-run elasticity & $\begin{array}{r}\text { Growth rate } \\
\text { per year. }\end{array}$ & $\begin{array}{r}\text { Predicted employment } \\
\text { growth }\end{array}$ \\
\hline Wage rate & -0.44 & $4.2 \%$ & $1.85 \%$ \\
Work intensity & -0.66 & $1.6 \%$ & $-1.08 \%$ \\
Efficiency & Negative & 2.4 to $3.8 \%$ & $4.20 \%$ \\
Capital stock & +1.00 & $+7.0 \%$ & $+7.0 \%$
\end{tabular}

Notes: The elasticities are derived from a dynamic model of employment determination estimated on an industry-region panel for 1979-1987 (see Bhalotra 1998a). "Efficiency is captured by time dummies and there is no straightfonward concept of an elasticity here. The estimates of the rate of growth of efficiency are derived from production function estimates in Bhalotra (1998b). $+A$ capital stock coefficient of unity is imposed after confirming that the data do not reject constant returns to scale. The sum of the predicted growth rates of employment in the final column is close to the actual growth rate of $-0.3 \%$ p.a. in this period.

Wage growth in this period is considered carefully in Section 7 below. The growth in productivity and in labour utilization can be argued to have arisen as a result of improvements in public infrastructure and deregulation of industry and trade. The first enabled and the second induced greater efficiency and the employment consequences were dramatic only because so much slack was inherited from the previous decade. What predictions does the forgoing diagnosis suggest? To the extent that the slowdown in employment growth is related to higher efficiency (e.g. unobserved effort on the part of workers), the long-run effect on employment is ambiguous unless further structure is

${ }^{5}$ See Layard, Nickell and Jackman (1991) for models of employment and wage determination under imperfect competition. See Bhalotra (1995, Chapters 3 and 4) for an application of these to the case of India.

${ }^{6}$ The wage is defined as real earnings per day worked. So it reflects true labour costs. 
imposed on the model. Higher effort levels lower the wage in efficiency units and so raise the demand for labour but, when every worker is more productive; one needs fewer workers per unit of capital. The net effect depends upon labour demand elasticity. To the extent that increases in the time intensity of work must hit a ceiling, this analysis predicts a restoration of employment growth: which is what we observe after 1986 (see section on the 1990 s record below). The rest of this subsection looks more closely at the driving forces of labour utilization and productivity.

\section{Labour utilization}

Between 1979 and 1987, nearly half of the increase in real earnings per worker was accounted for by an increase in time worked per worker (Nagaraj 1994, Bhalotra 1995, Chapter 4). It is estimated that a sixth of official working time was being lost in 1979 and that this was recuperated to a fair extent by 1987 (Bhalotra 1998a). The growth rate of time intensity was significantly different from zero in 14 of the 18 two-digit industries, averaging 1.64 per cent p.a. over the nine years.

The evidence suggests that the growth in labour utilization reflected a recuperation of lost time rather than overtime work (see Bhalotra 1995, chapters 4 and 5). What is it about the 1980s that brought this about? Might it relate to the introduction of economic reforms? The reforms probably generated increased uncertainty and competition amongst firms while at the same time reducing the bargaining power of workers, and these changes can be argued to have induced pressure to de-hoard surplus labour amongst firms, and discipline amongst workers (e.g. less time lost in strikes). Infrastructural investment also increased in this period (Ahluwalia 1991, Nagaraj 1990). This can explain recuperation of time losses on account of power shortages and materials shortfalls.

Estimates of the production technology in Indian manufacturing suggest that the output elasticity of time worked per worker is unity (see Bhalotra 1998b). This means that increases in labour utilization imply increases in capital utilization and vice versa. Discussions of increases in labour utilization often neglect to recognize this. It arises because labour and capital are complementary in production. If, for example, there are fewer strikes or there is more overtime work, then the machines in a factory will run more often.

\section{Productivity growth}

TFP in the 1980s grew at 2.4 per cent p.a. (Bhalotra, 1998b), marking a significant improvement from the previous decade and a half when there was no growth in TFP. The acceleration in TFP was observed in most industrial sectors (Ahluwalia, 1991). This is plausibly associated with the policy reforms. Ahluwalia (1991) argues that the reforms encouraged technological upgrading and modernization and Bhalotra (1998b) argues that increases in worker effort and skill in this period probably also contributed to the productivity increase. Human capital in manufacturing may have grown in the $1980 \mathrm{~s}$ if, for example, the least skilled were the first to lose their jobs. Worker effort may have increased either because their bargaining power was being eroded by the slowdown in employment or, if there were efficiency wages effects, because wages were rising in this period. There is some evidence from the Indian data that wages elicited effort (see Section 7). 


\subsection{Employment in the 1990s}

One way of judging whether we have a sound explanation of the slowdown in employment in the 1980s is to consider how well it can explain the recovery of employment growth in the 1990s. The growth in work intensity slowed to close to zero (0.14 per cent p.a). in the 1990-1997 period. This is in line with expectation and confirms the interpretation of the trend increase in work time in the 1980s put forward in Bhalotra (1995, 1998a) and Nagaraj (1994): if this reflected greater efficiency in labour use and the purging of an overhang, it would have to taper off. The growth in both wages and efficiency slowed a bit and capital accumulation increased more rapidly. Each of these changes will have encouraged employment growth. Let us now review the two papers that have offered explanations of the turnaround in employment growth.

Nagaraj (2000) proposes that increases in investment in the 1990s can explain increasing labour demand. Although the cost of capital (proxied by real interest rates in the economy) was higher in the 1990s than in the 1980s, he argues that the cost of capital for large private corporate firms was lower in the early 1990s as the stock market boom reduced the real cost of investible funds. The larger Indian firms also had better access to international capital markets. Nagaraj documents fixed investment growth increasing from 9 per cent p.a. in the 1986-1991 period to 15 per cent p.a. in the period from 1992 to 1997 and suggests that this investment boom may be a response to deregulation in industry and trade.

The explanation of employment trends in the 1990s put forward by Goldar (2000) rests on two factors. First, he points to a shift in the size structure of employment towards smaller establishments, which are typically more labour intensive. The size class 50-500 workers gained while the number of establishments in size classes in excess of 2000 workers shrank. Goldar argues that this is a result of economic reform peeling away the incentives for big size (protection, public sector domination etc). Debating this view, Nagaraj (2000) points out that the average size of the factory in Indian industry has been diminishing continuously since the 1950 s. In order to adjudicate between these claims, it would have been useful to establish whether the on-going changes in size structure have accelerated in the reform period, but this information is not available in these studies. A possibly more relevant point to pick with the Goldar argument is that it is unclear whether the pre-reform period was characterized by incentives for large size or by restrictions on size (see Section 2). As also discussed in Section 2, snapshot changes in size structure conceal the dynamics of change - and this is where the relevant information concerning the effects of reform is to be found.

The second factor to which Goldar attributes the employment recovery is a decrease in the rate of earnings growth relative to the 1980s. Nagaraj (2000) takes issue with this argument of Goldar as well. He argues that it is unclear that wages have a negative impact on employment, appealing to the idea that a decline in wages may depress aggregate product demand enough that aggregate labour demand falls. This argument neglects the fact that a decline in the wages of organized sector workers will have little impact on aggregate demand in India as they are a very small fraction of the population. In any case, we have seen that there is a well-identified negatively sloped labour demand curve in 
Indian manufacturing and that the wage elasticity of employment is -0.44 in the long run (Bhalotra 1998a) ${ }^{7}$. Goldar's argument that a slowdown in wage growth will have contributed to a pickup in employment growth is therefore valid.

\subsection{Child labour}

Participation rates of children and youth for 1993/94 and 1999/2000 by the "usual status" employment definition are in table 3 (see Sundaram 2001). There was a fairly substantial reduction in child labour for boys and girls aged 5.14 in both rural and urban areas. This is reflected in higher student-population ratios, also reported in the NSS. It may also be interesting to note that there was a decline in the worker-population ratio in older age groups as well (see Sundaram, 2001). To the extent that poverty drives child labour, the reduction observed may be explained by the recorded decline in poverty incidence during the same period. For an analysis of child labour and education in India see The Probe Team (1999) and Nielsen and Dubey (2002).

Table 3: Worker-population ratios by usual status for children, 1993/1994-1999/2000

\begin{tabular}{|c|c|c|c|c|c|c|c|c|}
\hline \multirow[b]{2}{*}{ Age } & 1993 & 1999 & 1993 & 1999 & 1993 & 1999 & 1993 & 1999 \\
\hline & \multicolumn{2}{|c|}{ Rural male } & \multicolumn{2}{|c|}{ Rural female } & \multicolumn{2}{|c|}{ Urban male } & \multicolumn{2}{|c|}{ Urban female } \\
\hline $05-9$ & 01.1 & 0.6 & 1.4 & 0.7 & 0.5 & 0.3 & 0.5 & 0.2 \\
\hline $10-14$ & 13.8 & 9.1 & 14.1 & 9.6 & 6.6 & 4.9 & 4.5 & 3.6 \\
\hline $15-19$ & 57.7 & 50.3 & 36.4 & 30.4 & 35.6 & 31.4 & 12.3 & 10.5 \\
\hline
\end{tabular}

Source: NSSO $(1996,2000)$. Usual status includes both principal and subsidiary employment. $M$ is male and $F$ is female. Drawn from Sundaram (2001), Table 2

${ }^{7}$ Consider an exogenous rise in the wage rate from $\mathrm{W} 1$ to $\mathrm{W} 2$. Let the corresponding profitmaximising levels of employment be $\mathrm{N} 1$ and $\mathrm{N} 2$. If $\mathrm{R}(\mathrm{N})$ is the revenue function then it must be true that R(N1)-W1N1 > R(N2)-W1N2 and R(N2)-W2N2 $>$ R(N1)-W2N1, which implies that $0 \geq$ (N1-N2)(W1-W2). In other words, irrespective of the shape of the revenue function, a ceteris paribus increase in the wage cannot encourage employment growth (Bliss, 1988). Nickell and Wadhwani (1991) show that this remains true in a union bargaining model as long as the objective functions of the two parties have the standard properties and the power of the union in the employment bargain does not exceed its power in the wage bargain. 


\section{Unemployment}

\subsection{Concepts and data}

There are, in general, no unemployment benefits in India (though the state of Kerala has experimented with this). This makes it difficult for the poor to be unemployed. Sensitivity to this fact is reflected in the way in which unemployment statistics are collected in India by the National Sample Survey Organization (NSSO). The usual status (URUS) rate counts persons unemployed for the most part of the year. An alternative measure, the daily status (URDS) rate, is a person-day rate that is sensitive to underemployment. The National Sample Survey is the only source of data on unemployment that is both conceptually sound and comparable across regions and time, and it has been conducted quinquennially.

Taking the most comprehensive measure of unemployment (the "current daily status" rate, which counts in underemployment), only 7.3 per cent of Indians were unemployed in $1999 / 2000$. In the same year, the percentage of the population below the poverty line was estimated to be 26 per cent. The Planning Commission (2001), for example, argues that this implies that large numbers of those in employment earn income levels that leave them below the poverty line. However, this argument is not the only plausible explanation of the data. The data are consistent with the view that the unemployed have an average of three dependents.

\subsection{The time pattern}

The overall unemployment rate increased from about 6 per cent in the mid 1980s to 7.3 per cent in 1999/2000. Since accelerating urbanization has caused the urban labour force to swell, the numbers unemployed in the urban sector have been rising rather more rapidly than the urban unemployment rate. The rural unemployment rate increased by about 2.5 percentage points in the $1990 \mathrm{~s}$, more than the urban rate did. For rural men, the increase in unemployment appears to be associated with a shift from self-employment to employment as casual wage labour. Although there is a gentle trend towards increasing rural proletarianization (Vaidyanathan, 1994) and casualization of the urban work force (Minhas and Majumdar, 1987), this set in before the reforms were introduced. It is interesting to note that, for persons with secondary education and above, there was a reduction in unemployment probabilities (using the usual status definition) (see Sundaram 2001). This suggests widening inequality in well-being between the educated and uneducated.

The rise in the unemployment rate in the 1990s need not signify a permanent reduction in job opportunities. During an economic transition, workers need to move between sectors and regions in response to expected wages - in the direction of higher productivity. Unemployment may then simply signify the friction involved in this process. In this case, it is expected to be transient. There is no research on the dynamics of unemployment in India but with the recent availability of micro-data from the NSS this is feasible. Was unemployment higher on account of higher rates of entry into the pool of unemployment or was there a decline in exit probabilities? What was the average duration of unemployment, and did this show any lengthening in the 1990s? Answers to these questions will help interpret changes in the unemployment rate. This, of course, is essential to devising policies to reduce unemployment. 


\subsection{The regional pattern}

Unemployment rates vary dramatically across the regions of India. The Indian states are comparable in size to the European nations. Differences in unemployment rates across European nations have stimulated research, the focus being on differences in labour market institutions (e.g. see Layard, Nickell and Jackman 1991). In India, the question of what underlies unemployment differences involves understanding migration as well as statespecific economic and institutional features.

The four southern states (Kerala, Tamil Nadu, Karnataka and Andhra Pradesh), along with West Bengal in the east of the country, have the highest unemployment rates. The contiguous states of Uttar Pradesh, Madhya Pradesh, Orissa and Bihar, which occupy the north-central region of the country, are amongst those with the lowest incidence of unemployment. This distribution of unemployment rates across states is interesting in at least two ways. One is that, broadly speaking, the states with a higher incidence of poverty have lower unemployment rates and conversely. It seems therefore that poverty incidence or real per capita income (the two are found to be highly correlated) acts like a negative benefit rate. The second is that blocks of states constitute high (such as the entire southern part of the country) and low unemployment areas (such as the 'cow belt' in the northcentral region). Is the common factor between these 'clusters' a purely geographic feature like climate (determinant of agricultural performance), some aspect of shared 'culture' such as education levels, or can it be directly related to economic variables such as industrial development? The regional distribution of industrial growth in India is very uneven but there is no careful analysis that illuminates the question of how this is related to the distribution of unemployment.

In $1972 / 73$, unemployment by the daily status measure was 23 per cent in Kerala and 4.3 per cent in Uttar Pradesh, and three decades later, in 1999/2000, this range was much the same, with Kerala having an unemployment rate of 21 per cent and Uttar Pradesh a rate of 4.3 per cent! There was similarly little convergence in usual status unemployment. In addition, the ranking of states by unemployment rates exhibited considerable rigidity over time. Rank correlations of quinquennial observations in the period from 1972 to 1987 lay between 0.70 and 0.88 . The stability of the regional unemployment rate structure is puzzling. This is because, controlling for labour force composition, the unemployment effects of region-specific shocks are expected to be neutralized in the long run by wage flexibility and factor mobility. The fact that big unemployment differentials persist in India commands investigation of the responsiveness of wages to unemployment and migration behaviour. India's relative abundance of labour may be expected to encourage wage flexibility, and widespread poverty motivates substantial migration for jobs. Yet neither wage flexibility nor migration appears to have brought about any significant degree of convergence in the regional unemployment rate structure. Understanding these processes is crucial to understanding employment and unemployment in India. Wage flexibility is an important property for getting markets to work and offer the correct signals and, similarly, migration in response to differences in expected wages is an essential part of restructuring in response to liberalization. The enormous regional variation in unemployment is exploited in Bhalotra (1996) to analyse these questions. Relevant sections of this research are now discussed. 


\subsection{Alternative explanations of persistent unemployment rate differentials}

An explanation of long-run differentials in unemployment rates can appeal to any of the following possibilities. (1) Barriers to migration. These may be financial, social and psychological costs or legal barriers. There are no legal barriers to movement between the Indian states. While language varies by state, urban residents tend to know a common language. Indeed the evidence, surveyed by Papola (1992, p.41), is that there is substantial labour mobility in response to employment opportunities, both within and across states. And restoration of spatial equilibrium only requires a very small fraction of a region's population to move (see Marston, 1985). Thus, while costs will affect the speed of adjustment to equilibrium, it seems unlikely that they can account for a geographical pattern of unemployment that has remained stable over a period of fifteen years. (2) Compensating differentials. If regions with relatively high unemployment rates have higher wages and offer better living conditions ("amenities") then the observed differentials constitute an equilibrium (see Hall 1970, Harris and Todaro, 1970). (3) Disequilibrium on account of countervailing rural-urban flows. A third possibility is especially relevant in a developing economy where every urban region has a rural hinterland attached to it and where it is reasonable to assume that the speed of rural-urban migration exceeds the speed of urban-urban migration. Urban-urban migration may occur from high to low unemployment regions but this disturbs the rural-urban equilibrium, stimulating a flow of rural-urban migration in high unemployment states and urban-rural migration in low unemployment states. As a result of these rural-urban flows, urban-urban unemployment differentials across states are maintained. ${ }^{8}$ If the stock of potential migrants in the rural sector is large enough, there is perpetual disequilibrium. See Bhalotra (1996) for a formalization and test of this hypothesis.

Investigation of these three alternatives using a panel of quinquennial data for the Indian states suggests the following. First, migration does appear to occur in the direction of expected wages and barriers do not seem to be binding. In the long run, regions with high wages and good amenities attract high unemployment, consistent with the compensating differentials story. However, the tendency towards an equilibrium in interstate urban unemployment differences is upset by the more speedy tendency for urban regions to equilibrate with their neighbouring rural regions: the urban sector of any state is unable to 'run away' from its rural sector. There is hence some support for the third view.

Future research investigating the three sector model proposed here using more frequent observations at a lower level of disaggregation is merited. We have left unexplored the related question of whether it stimulates in- or out-migration of firms. An enquiry into the determinants of the distribution of industrial capital in India is likely to be a rewarding, if formidable, task.

\subsection{Labour demand and unemployment rates}

An important insight gained from modelling the long-run regional labour market equilibrium is this: equilibrium wage and unemployment rates in the long run are independent of demand: demand increases the volume of employment but, in equilibrium, it also increases the labour force of the region (through migration) by just so much as to leave the employment rate unchanged (e.g. Jackman, Layard and Nickell 1991).

8 The rural-urban movements are conceived of as intra-state. The existence of interstate rural-urban flows does not upset the structure of the model as long as, on average, friction associated with interstate flows is greater than that associated with intrastate flows. 


\subsection{The wage-dampening effect of unemployment}

The unemployment elasticity of wages is estimated to lie between -0.24 and -0.28 . This effect is about twice as large as observed in a range of other countries (see Blanchflower and Oswald 1992). So, within regions, wage growth is dampened by the presence of unemployment and, contrary to popular opinion (e.g. Holmstrom 1976), Indian factory workers are not entirely insulated from conditions on the market outside. The rosy picture of unlimited supplies of labour available at a fixed wage to fuel industrialization that is characteristic of the early development literature (e.g. Lewis 1954) is not upheld by the data, which support a labour supply curve that slopes upward. ${ }^{9}$

The size of the unemployment elasticity depends upon the extent to which the prospect of job loss tempers wage demands (see Layard, Nickell and Jackman 1991, for example). If India's exceptionally strict job security provisions were effective then we should expect to see a small elasticity. The appearance of such a large elasticity suggests that the scope and effectiveness of the job security law is limited (and/or that Indian workers are very averse to risk). ${ }^{10}$ This is relevant to the topical question of whether there is urgent need to reform this law (see Section 4 above).

\subsection{The long-run wage-unemployment relation across regions}

Across regions, the long-run relation of regional unemployment and wages is positive. ${ }^{11}$ A positive wage differential of 10 per cent is associated with a positive unemployment rate differential of 0.25 percentage points or 2.6 per cent. While the wage effect is significant, it is small and amenities and compositional variables appear to bear the weight of the explanation of unemployment rate differentials.

The usual status urban unemployment in a state is a positive function of left-wing government, public sector predominance, the literacy rate, the rural unemployment rate, the rural-urban labour force ratio, and the percentages of casual and construction workers. Additional variables that impact only on the broad measure, that includes underemployment, are residence in a metropolis, the fraction of youth, the fraction holding regular jobs and the percentage of landless workers. One important finding here is that conditions in the rural labour market have a significant impact on the conditions of urban workers. Also, states with a higher fraction designated as 'lower' castes have lower unemployment, probably a reflection of lower reservation wages in this group. (Based on a survey in Delhi, Mehta (1988) reports that this group constitutes a major fraction of the urban poor). ${ }^{12}$ States with more literate populations have higher unemployment, ceteris

\footnotetext{
${ }^{9}$ Strictly, a labour supply curve is not defined under imperfect competition but there is an analogous relation, which has been called the wage curve or wage-setting function. This slopes downwards in the wage-unemployment space but upwards in the wage-employment space.

${ }^{10}$ Bear in mind that the wage here is the factory wage. Job security provisions covered only 56 per cent of factory workers in 4 per cent of establishments during the 1976-1982 period. After 1982, coverage was extended to encompass 72 per cent of workers, in 11 per cent of establishments (based on Annual Survey of Industries, 1986).

11 The long run is defined as a period long enough to permit migration. In the short run, by contrast, the labour force of a region is fixed.

12 The mobile are choosers. If 'low caste' people are relatively immobile on account of poverty or inadequately developed contacts, then changes in local demand conditions will impact relatively strongly on their wages. The more mobile will migrate out of the region (see Topel, 1986). The interaction term between 'low-caste' and poverty incidence is insignificant.
} 
paribus. This may be seen as reinforcing a queuing model of unemployment wherein the literate are more selective - the positive sign suggests a supply-side rather than a demandside effect.

\subsection{Kerala: the outlier}

The state of Kerala is an outlier in the unemployment distribution and the persuasiveness of a model may be judged, amongst other things, by its success in explaining outliers. The relatively high unemployment rate in Kerala has recently claimed attention (see Ramachandran, 1997). A popular explanation is that industrial capital is unwilling to locate there because of the adverse climate of labour relations (e.g. Kannan, 1992). Consequently, there are few new jobs. While this may explain why capital does not enter the state, the question of why labour does not leave remains to be answered. The analysis in this paper provides a new perspective on this question. Kerala has fierce wage push on account of widespread education and unionization, it has the highest rates of literacy and rural unemployment in India, and is well-endowed with amenities, its residents enjoying better education, health and social security provisions than in any other region of India. These are all factors that, unlike demand, are slow to change and, in terms of the model in Bhalotra (1996), can explain relatively high unemployment in Kerala.

\section{Wages: Growth and distribution}

\subsection{Wage growth in the reform era}

The daily average wage rate of casual wage labourers in India increased significantly in real terms during the period from 1993-1994 to 1999-2000, at a rate of about 3.5 per cent p.a. Though there was a fall in work participation rates in this period, earnings increased at a positive rate of about 2.5 per cent p.a. This growth in earnings was evident for males and females in both rural and urban areas, the rate of growth being higher for females than for males in both areas (based on NSS data: see Sundaram, 2001). Wages in organized manufacturing displayed a similar trend, increasing at about 2.5 per cent p.a. in the 1990s (1990-1997), a bit slower than in the previous decade (1980-1990), when the rate of growth was about 3.6 per cent p.a. (e.g. Goldar 2000). Overall, wages and earnings appear to have increased more rapidly since economic reform was introduced. This is consistent with the higher growth rate of labour productivity in organized manufacturing as well as in the broader economy. It has no doubt contributed to the decline in poverty incidence observed between 1993/94 and 1999/2000 (e.g. Sundaram 2001).

\subsection{Wage structure}

The most remarkable feature of the wage structure in India is the enormous wage differential between the organized and unorganized sectors. In the context of the on-going debate on North-South trade and wage inequality (e.g. Wood 1995, Jones and Engerman 1996), it would be interesting to investigate how the skilled-unskilled wage differential has changed in the last two decades, while economic reforms have liberalized the trade regime. However, there appears to be no research as yet to illuminate this question for India. Until recently, there were no data on the education and skill of workers in India.

Organized-unorganized sector wage inequality has generated concern for distributional reasons. It is a widespread belief that government protection of labour and product markets has contributed to the isolation of the factory sector from the rigours of the market (e.g. Fallon 1987, Lucas 1988, World Bank 1989). This generates two concerns. 
First, a concern with inequality created by "undeservedly" high wages. Second, a concern with "excessively" high wages discouraging labour demand in the organized sector. ${ }^{13}$ Adherents of this view demand policy reforms that curb union power and revoke job security legislation. Indeed, these demands are currently central to the controversy over India's new economic policies which, so far, have concentrated on product market deregulation. It is important, in this context, to understand wage determination and how it ties in with the determination of employment, productivity and growth. For these reasons, we now consider in some detail the processes underlying wage-setting in the factory sector.

In developed countries, non-competitive wage-setting may imply a wage-price spiral, given imperfect competition in product markets. The same process is possible in India, given the oligopolistic nature of registered sector industry. However, it is unlikely to be as central, given that [a] the share of labour costs, at 40 per cent, is outweighed by the share of material costs in production (Chatterji, 1989); and [b] the consumer price index is dominated by food prices, the prices of factory goods being relatively insignificant (Tulpule and Dutta, 1988). Thus, interest in non-competitive wage setting in India is better motivated by its implications for employment quantity and quality than by its inflationary potential.

Even within the organized sector, there are striking differentials by industry and state. These are described below.

\subsubsection{Inter-state wage differentials}

In the 1980s, nominal earnings in Andhra Pradesh were almost 50 per cent below the India average, and those in Maharashtra almost 50 per cent above (column 1, Table 4). Thus earnings in Maharashtra were three times earnings in Andhra, a fantastic range for neighbouring states. These wage differentials were remarkably stable, showing no tendency to narrow between 1979 and $1989 . .^{14}$ The state variation in earnings was recomputed after controlling for differences in industrial compositional ${ }^{15}$ (column 2, Table 4). The pure state effects thus identified are still very large, the standard deviation (s.d.) of adjusted log earnings being 20 per cent (compared to 32 per cent before controlling for composition). This is reinforced by the data in column 3 of Table 5 ? which show the dispersion of earnings within each industry across states. For example, the s.d. of Chemical wages is approximately 45 per cent of its mean. Thus despite considerable migration across states, there appears to be state-specific labour markets. Since controlling for industrial composition reduces the regional dispersion in earnings, it is evident that composition effects work in the direction of widening the extant earnings structure. Thus, not only is it meaningful to speak of inherently low-wage states, but it appears that low-

${ }^{13}$ On this particular question, see the estimates of the wage elasticity of employment reported in the Section on Employment. They are negative, as is to be expected, but not as large as may have been suspected.

${ }^{14}$ The study from which these estimates are drawn (Bhalotra 1995) does not include data for the 1990 s, as these were unavailable at the time of the study. It would be interesting to update the analysis presented here to see if wage differentials have contracted under liberalization.

${ }^{15}$ A state's industrial composition is bound to affect its average industry wage. Indeed, the lowwage states of Andhra and Kerala are dominated by Leather and Wood respectively, both of which are low-wage industries. At the other end of the spectrum, Bihar and Orissa have a concentration of heavy Basic metals industries and Maharashtra hosts the 'sunrise' (growing) petrochemical industries. 
wage industries are attracted to low-wage states, and vice versa. This would make sense if, for example, inherently low-wage regions had populations with low education and skill levels.

Table 4: State wage differentials

\begin{tabular}{|c|c|c|c|}
\hline & $\begin{array}{r}\text { (1) } \\
\text { Composition } \\
\text { Variable } \\
\end{array}$ & $\begin{array}{r}(2) \\
\begin{array}{r}\text { Composition } \\
\text { constant }\end{array} \\
\end{array}$ & s.d. of log earnings \\
\hline Andhra & -48.85 & -20.62 & 0.503 \\
\hline Kerala & -33.38 & 24.89 & 0.831 \\
\hline Punjab & -16.34 & -15.57 & 0.241 \\
\hline Uttar Pradesh & -9.10 & -02.56 & 0.426 \\
\hline Tamil Nadu & -6.18 & -4.50 & 0.467 \\
\hline Haryana & -5.90 & -5.56 & 0.307 \\
\hline Gujarat & -2.64 & -2.76 & 0.345 \\
\hline Kamataka & -3.08 & 0.13 & 0.430 \\
\hline Delhi & -3.13 & 0.11 & 0.291 \\
\hline Madhya & -5.62 & -8.51 & 0.584 \\
\hline Rajasthan & -10.19 & 2.68 & 0.294 \\
\hline Orissa & -29.99 & -19.34 & 0.633 \\
\hline Bihar & -31.00 & 0.38 & 0.481 \\
\hline West Bengal & -42.63 & 39.74 & 0.334 \\
\hline Maharashtra & -9.40 & 42.00 & 0.360 \\
\hline Weighted s.d.(logs) & -0.316 & 0.203 & \\
\hline \multicolumn{4}{|c|}{$\begin{array}{l}\text { Notes: From Bhalotra (1995, Chapter 3). Figures in col.1\& } 2 \text { are in \%s and refer to nominal earnings. They are } \\
\text { computed as deviations from the mean, using [exp(Dw)-1]"100, where Dw=(in ws-In w), ws=state wage \& w=India } \\
\text { wage, both averaged over 1979-87. In col. } 1 \text {, ws= Si(Nis/Ns)wis and in col.2, ws=Si(Ni/N)wis, where the data are } \\
\text { averaged over time without weights, subscripts 'i' and 's' denote industry and state \& no subscript denotes the all- } \\
\text { India average. In the last row are the weighted standard deviations of logged wages, obtained as s=Ss(Ns/N)[ws-w]2 } \\
\text { in col. } 1 \text { and } \mathrm{Ss}[\text { ws-w]2 in col.2. Col.3 shows industry dispersion within each state. Average state earnings are } \\
\text { obtained as ws=Si(Nis/Ns)wis. Then the standard deviation of state earnings around the industry mean is } \\
\mathrm{s=Si(Nis/Ns)[wis-ws]2.}\end{array}$} \\
\hline
\end{tabular}

\subsubsection{Inter-industry wage differentials}

Earnings differentials between Indian industries are huge (column 1, Table 5). In the period from 1979 to 1987, nominal earnings in Transport Equipment were four and a half times those in Tobacco \& Beverages. The s.d. of log earnings is 46 per cent, considerably larger than observed in a diverse set of other countries (Table 6) and it does not vary a lot with time.

The industry earnings ranking fits nicely with the impression that capital or technology intensive industries pay high wages. These tend to have high output per worker, and a small share of labour in total costs (Marshall's "importance of being unimportant"). Both factors make it more likely that they can afford relatively high wages. Upon holding industrial location constant (column 2, Table 5), the differentials narrow but the ranks hardly change. Dispersion is down from 46 per cent to 36 per cent. Hence region effects on the industry distribution are rather weaker than industrial composition effects on the regional structure. This is underlined by a comparison of columns 3 in Tables 5 and 5 . Table 4 shows that the dispersion of industry earnings within half of the states is greater than the all-India industry dispersion. 
Table 5: Industry wage differentials

\begin{tabular}{|c|c|c|c|}
\hline & (1) & (2) & (3) \\
\hline Industry & Location variable & Location constant & s.d. of $\log$ earnings \\
\hline Tobacco \& beverages & -63.28 & -42.16 & 0.388 \\
\hline Food products & -48.00 & -45.03 & 0.339 \\
\hline Wood \& furniture & -41.81 & -42.08 & 0.166 \\
\hline Textile products & -31.76 & -34.56 & 0.400 \\
\hline Cement, glass etc & -22.48 & -18.43 & 0.258 \\
\hline Leather \& fur & 13.74 & -17.59 & 0.279 \\
\hline Metal products & -4.38 & -7.41 & 0.381 \\
\hline Wool \& silk textiles & 9.99 & 6.09 & 0.285 \\
\hline Cotton textiles & 11.89 & 5.25 & 0.175 \\
\hline Miscellaneous & 14.58 & 0.14 & 0.366 \\
\hline Paper \& publishing & 20.06 & 15.55 & 0.173 \\
\hline Petroleum \& rubber & 25.44 & 11.48 & 0.289 \\
\hline Chemical products & 35.18 & 33.99 & 0.451 \\
\hline Non-elec machinery & 36.42 & 33.87 & 0.247 \\
\hline Electricity & 46.28 & 47.77 & 0.191 \\
\hline Basic metals & 51.76 & 27.16 & 0.370 \\
\hline Electrical machinery & 54.08 & 45.37 & 0.261 \\
\hline Transport equipment & 63.03 & 52.73 & 0.268 \\
\hline weighted s.d.(logs) & 0.462 & 0.360 & \\
\hline
\end{tabular}

Table 6: Industry wage dispersion in selected countries

\begin{tabular}{lr}
\hline Country & s.d. of Industry Wages \\
\hline Bolivia & 0186 \\
Canada & 0.239 \\
France & 0.126 \\
Germany & 0.141 \\
Japan & 0.263 \\
Korea & 0.314 \\
Mexico & 0.155 \\
Norway & 0.107 \\
Poland & 0.097 \\
Sweden & 0.081 \\
USSR & 0.101 \\
United Kingdom & 0.140 \\
United States of America & 0.241 \\
Yugoslavia & 0.120 \\
India & 0.460 \\
Source: Krueger and Summers (1987): Table 2.12. & \\
\end{tabular}




\subsection{Imperfectly competitive labour markets?}

While there is a wide range of incomes among the self-employed, the casual wage is, on average, only a third of the regular wage (Sarvekshana 1990). Thus, there is fierce competition for regular jobs. By this token, one might expect the extent of effective unemployment to have an impact on the wage in regular employment, or even to 'beat it down' to the competitive level. Why then do wages in registered manufacturing exceed the supply price of labour? Why is the excess labour outside this sector unable to get jobs here by offering lower wages? One answer, of direct relevance to discussions of economic liberalization, is that protected product markets have yielded substantial rents which organized workers in large firms have successfully contended for a share of. Also, with the introduction of job security legislation for large firms in 1976, the disciplining effects of the threat of job loss were probably mitigated, encouraging workers to raise wage demands. Alternatively, firms may have had to use the wage as an incentive instrument to get job-secure workers to exert effort. In this context, it is interesting to investigate the extent to which "inside" forces matter in wage determination in relation to "outside" or market forces measured by labour abundance.

\subsection{Wage determinants: a summary of findings}

This section discusses GMM estimates of an earnings equation for production workers in Indian factories obtained using a panel of industry-state data for the 1979-1987 period (see Bhalotra 1995, Chapter 3). These are the only robust estimates of the impact of both unemployment and productivity on the wage level in Indian manufacturing. They identify effects that are consistent with both bargaining and efficiency wage theories. Significant influences on wages are found to flow from productivity, factory size, work intensity, the regional cost of living, and comparison wages and unemployment rates in the region. These variables explain $80-90$ per cent of the time variation in wages but only about a third of the cross-sectional variation. There is some evidence that inflation surprises induce changes in real wages, or that there is nominal inertia. Since wage contracts are written for longer than a year and Dearness Allowances do not imply price neutrality (except for the very lowest-paid workers), this is unsurprising. The significance of the first and second lag of the wage rate indicates real wage inertia. This suggests that the real wage is not the ideal market clearing instrument.

\section{Implications for policy reform}

The results carry the following relevant implications. Labour markets in India are severely segmented along both industry and state lines. Improvements in productivity are shared with workers and, to that extent, do not translate into increases in employment in the short run. In the long run, however, the existence of insider wage setting is expected to have no implications for the employment effects of technical change if the product market is competitive. This is because competitive forces will ensure that these gains are eventually spread through the population via their impact on product prices (e.g. Layard, Nickell and Jackman 1991). What is clear from the analysis, however, is that wages are not market clearing irrespective of government interventions. Therefore, analyses that recommend the removal of all state machinery in the labour market as a cure for its ills are likely to be barking up the wrong tree. Although unemployment does not drive wages down to the competitive level, it does exert a dampening force. 
Models of development (e.g. Lewis 1954, Harris and Todaro 1970) that still shadow academic thought and policy-making in labour-surplus economies have tended to assume an institutionally determined and rigid wage in the urban 'formal sector'. A demonstration of the flexibility of this wage, to both unemployment and productivity changes, overturns this conventional wisdom and, in some cases, leads to a significantly revised view of the development process.

The rest of this Section offers further detail on wage determination.

\section{Insider (industry-specific) forces}

How much do insider forces modify the wage relative to market (or outside) forces? The difference between the medians of the top and bottom quartiles of the wage distribution is 17 per cent, termed the insider gap. ${ }^{16}$ Thus on account of industry-specific factors (productivity, factory size and work intensity) alone, we may expect to see pay differentials widen by 17 per cent. The gap on account of productivity alone is estimated to be 12 per cent.

The elasticity of wages with respect to productivity is 0.21 . Productivity accounts for about one- fourth of the variation in earnings, on average, whether across industries or over time. There are large inter-industry differences in the contribution of productivity. Thus, it explains virtually all of the wage differential in Petroleum, and almost none of that in Cement. An interesting question is whether the productivity effect on wages is symmetric, that is, whether it is wages and not jobs that suffer the brunt of bad times. India's employment record in the 1980s appears consistent with the hypothesis that the insider effect is asymmetric, that is, larger in good than in bad times. By this hypothesis, growing industries will have healthy wage growth and relatively slow growth in employment, while shrinking sectors will exhibit only a small slackening of wage growth and rapid downward adjustment of employment. So in a period of 'industrial turbulence' such as the 1980s in India, on average, one may expect to see healthy wage growth together with little growth in employment (Bhalotra 1995, Chapter 3). And this is precisely what we see. Industries like Chemicals that were gaining in value added share had rapid wage growth without a significant acceleration in employment, whereas in declining sectors like Cotton and Jute Textiles, employment seems to have borne most of the adjustment. Interesting in view of their being wholly and largely in the public sector, respectively, Electricity and Basic Metals were the only two declining sectors where wages, and not employment, suffered. This reinforces our understanding of public sector commitment to employment but it challenges the view that its management is disengaged from economic realities.

The coefficient on work intensity (days worked per worker) in the earnings equation is 0.50 , which is argued to be consistent with there having been a fair amount of "undertime" work in this period, or with labour having been hoarded. ${ }^{17}$ So, of relevance to the analysis of employment above, we find that additional days worked cost the employer

${ }^{16}$ This procedure in adapted from that followed by Nickell and Wadhwani (1990b). The insider gap for their firms is 18 per cent (period: 1972-1982; large firms: $5000+$ employees on average).

17 Undertime refers to a situation where workers work for less time than they are paid for. It is not to be confused with the opposite of overtime and associated notions of overtime pay. The extent to which undertime influences earnings depends on pay arrangements. Personal enquiries indicate that regular factory workers are paid by the week or the month, rather than the day. 
less in terms of wages than do additional workers. ${ }^{18}$ The total impact of work intensity on earnings is 0.71 , obtained by adding in the indirect effect working through productivity, using production function estimates for the same sample. There is a small but significant effect of average factory size on wages of 0.13 , which appears to contribute mostly to explaining the cross-sectional variation in the data.

Hysteresis effects do not require unions, and may be expected in general, in the absence of corporatist wage-setting. The idea is that bargainers can claim larger wage increases the smaller is the incumbent work force whose survival is to be ensured (Blanchard and Summers, 1986). Evidence of hysteresis is confined to 3 out of 18 industrial sectors in India (Food-Processing, Transport Equipment and Petroleum \& Rubber). This is a good sign as it implies that adverse shocks do not have persistent effects on the economy.

\section{The state of play outside}

Outside earnings, measured as the state-level average wage, enter the earnings equation with a long-run coefficient of 0.37 . So, the inside wage is modified by outside wages. The state-level unemployment rate has a marginal effect of -0.41 on the state fixed effects in the wage equation. The dependence of wages on unemployment implies that the factory sector faces an upward sloping wage-setting curve, not the perfectly elastic labour supply curve that is still commonly assumed in the literature on less-industrialized economies. Just less than half ( 0.43$)$ of any increase in the cost of living is compensated by increases in nominal earnings. In an agrarian economy the wedge between the cost of living and the price of manufactures can be significant. The joint behaviour of product wages and the price wedge has inspired interest in India in the context of the wage-goods constraint (e.g. Chakravarty 1974) but, so far, quantitative evidence has been thin. The fact that workers obtain cost-of-living adjustments may be regarded as evidence that unions in the factory sector do wield some power. Alternatively, if efficiency wage considerations predominate, then it appears that efficiency depends on the consumer wage. Of course, efficiency wages and wage bargaining can operate in conjunction. Other aggregate variables have no independent effect on the wage. Unidentified fixed industry effects explain more than half of the inter-industry variation. The weighted s.d. of these is 0.23 , which is very substantial.

\subsection{Efficiency wages}

Unions and job protection are thought to nurture wage push and, thereby, to conflict with the objective of encouraging private enterprise. It has not been recognized, in this context, that private manufacturers might have volunteered wage increases and that this is entirely consistent with profit maximization on their part. Nor has it been appreciated that wage-induced effort might have contributed to the remarkable increase in the rate of total factor productivity growth in the 1980s. An exception is Deshpande (1992, p.91) who admits the possibility that rising consumption wages might improve nutrition and morale.

In an efficiency wage model, the additional revenue reaped by the payment of wages in excess of the supply price of labour offsets the additional cost incurred (see Katz 1996, for example). This simple fact affords a direct test of the efficiency wage hypothesis which

18 In the standard analysis, there is a trade-off between the overtime premia associated with increased time input per worker and the fixed cost associated with an increase in the number of workers (e.g. Hamermesh, 1993). In the Indian case, as increases in time appeared to represent catching up on earlier lost time, it is unsurprising that they do not seem to attract overtime premia. 
can be implemented by estimating a production function that includes wage-dependent effort. This is done for Indian factories during the 1979-1987 period in Bhalotra (1998c), who finds evidence consistent with the view that efficiency wages are paid in Indian factories, and that they pay for themselves. The latter finding undermines the importance of union wage bargaining. This study also finds that the profit function is very flat in the neighbourhood of the optimum. A 10 per cent deviation in the wage is estimated to result in a profit loss in the region of 0.2 per cent- 0.6 per cent. Given this and the fact that Indian manufacturing in the 1980 s was sufficiently protected from competition to allow some degree of slack, firms may well have indulged union or government demands for wage premia slightly in excess of the efficient wage. What is interesting from a policy perspective is that if a union presence does not cost employers very much then curbing union power is not guaranteed to generate lower wages and higher employment in factories. The emphasis (e.g. Planning Commission 2001) on policy attempts at making markets competitive by undoing various regulations is misplaced if the uncompetitiveness in the labour market results from technological features of certain sectors of industry that lead to a dependence of productivity (or, more generally, profits) on wages.

Small as it currently is, the manufacturing sector is expected to drive job creation in the economy, and so to effect the structural transformation. This process, however, is coming up against a 'rigidity' that was not envisaged by development planners, namely that worker effort is an important determinant of productivity, and needs to be nurtured, inter alia, by the provision of wage incentives. The fact that higher wages induce higher productivity will generate a positive employment effect, the size of which depends upon demand elasticity. The role of policy here is not straightforward. For instance, if efficiency wage considerations are the driving insider force, there is not much scope for direct policy intervention. If, instead, factory unions are driving rent-sharing, policy initiatives aimed at job creation will have to consider carefully whether economic reforms that alter product market structure are not more important than interventions designed to curtail union power.

These results would, of course, be more convincing if they emerged from investigation of firm-level data. Were the necessary detail available, it would also be interesting to investigate efficiency wage-setting in public versus privately owned firms, in union versus non-union firms and in large versus small firms. Further work is also desirable on the question of why efficiency wages are needed to elicit effort. Important questions of the health and nutrition standards of workers on the one hand, and of job security on the other potentially tie in with an understanding of this: do firms need to pay efficiency wages because workers are unable to work hard unless they are paid uncompetitively high wages, or because they are all shirkers in the knowledge that their jobs are secure?

\section{Productivity}

\subsection{Economy-wide productivity growth}

The NSS data from the Employment-Unemployment Survey permit statements about labour productivity across the organized and unorganized sectors. Analysing these data, Sundaram (2001) reports a growth rate of 6 per cent p.a. between 1993-1994 and 19992000 in the economy as a whole and this seems to reflect growing productivity across all sectors (except for construction, where productivity was stagnant). 


\subsection{Productivity growth in organized manufacturing}

Manufacturing is a small but growing and relatively productive sector in India. The share of manufacturing output in GDP grew from $10 \%$ in 1951 to $33 \%$ in 1991 , in which time its share in employment grew from $11 \%$ to $16 \%$ (Papola, 1992), dropping again to $11 \%$ in 1999/2000 on account of productivity increases in the 1990s. Similar figures for the UK provide a useful contrast. The output share of manufacturing declined from $37 \%$ in 1960 to $22 \%$ in 1991 , and its share in employment behaved almost identically, falling from $37 \%$ to $23 \%$. Although the formal sector accounts for $70-80 \%$ of manufacturing output, it generates only $20 \%$ of manufacturing employment.

Concomitant with the slackening of employment growth starting in the early 1980s was a surge in output growth in the factory sector and in the wider economy. Capital productivity, which had exhibited negative growth during the previous two decades ceased to decline. As a result, there was an acceleration in total factor productivity (TFP) of apparently unprecedented magnitude in India. This slackened somewhat in the 1990s as the growth rate of both employment and investment increased to fuel growth. Overall, however, productivity growth has been significantly positive for the two decades since the onset of the reforms. The growth rate of TFP is estimated to have been 1.8 per cent p.a. during the period from 1979 to 1987 . There do not appear to be any reliable estimates of more recent growth rates. 19

The turnaround in productivity following fifteen years of negative or zero growth20 has been acclaimed as the reward of the deregulatory measures that were phased through the decade (see Ahluwalia 1991, Bhalotra 1998b). The de-licensing of several industrial sectors together with the lowering of import restrictions will have increased entry and so raised competition and output. There appears to have been considerable modernization of capital stocks and upgradation of technologies (e.g. Ahluwalia 1991, p.92). For reasons discussed under Employment above, the reforms appear to have stimulated increases in labour utilization as well as in worker effort and overall efficiency.

\subsection{The production technology in Indian manufacturing}

This Section discusses relevant findings of the estimates of a production function estimated on an industry-state panel for the 1979-1987 period (see Bhalotra, 1998b). Production at the industry level exhibits constant returns to scale. There appear to be no significant production lags, and the data reject the quadratic capital intensity term suggested by approximations to the CES and Translog functions. Industry-time dummies are included to control for industry-specific efficiency including changes in skill composition and input prices. While they are jointly highly significant, their inclusion does not change the estimated production parameters. The estimates imply that workers are, on average, not paid their marginal product. ${ }^{21}$ This signifies imperfect competition in product

19 Using the methods typically used to estimate productivity growth in India gives a TFP growth rate of 3.4 per cent p.a. from 1979 to 1987 . Stating a growth rate for the 1990 s using this method would thus be misleading - particularly as it would suggest an increase in the growth rate from the 1980 s to the 1990 s which would seem to be defied by the raw evidence on the growth rates of output, labour and capital.

${ }^{20}$ Krishna (1987) surveys estimates of productivity growth during the period from 1950 to 1980.

21 The output elasticity of employment, $\beta_{\mathrm{n}}=\partial \ln \mathrm{Y} / \partial \ln N=\mathrm{MP}_{\mathrm{N}} / \mathrm{AP}_{\mathrm{N}}$, where $\mathrm{Y}$ is output, $\mathrm{N}$ is employment, MP is marginal product, $\mathrm{AP}$ is average product. The share of labour, $\alpha=\mathrm{WN} / \mathrm{PY}=$ $(\mathrm{W} / \mathrm{P}) / \mathrm{AP}_{\mathrm{N}}$. Thus, $\beta_{\mathrm{n}}>\alpha$ implies $\mathrm{MP}_{\mathrm{N}}>(\mathrm{W} / \mathrm{P})$, where $(\mathrm{W} / \mathrm{P})$ is the product wage. In fact, it can be shown that, under imperfect competition, $\mathrm{MP}_{\mathrm{N}}=(1+\mu)(\mathrm{W} / \mathrm{P})$ where $\mu$ is the markup. 
markets, which can be characterized in terms of there being a positive markup of price on marginal cost (see Hall 1986). The average markup in Indian manufacturing is estimated as 19 per cent. The model that includes industry-time dummies implies a markup of 43 per cent. An interesting direction for future research would be to estimate the markup in this manner in the post-reform period to see how much increased competition has eroded the markup.

An important finding is that the hours elasticity of output is insignificantly different from unity. This implies that higher hours raise capacity utilization, which is of particular interest in the Indian context, where chronic under-utilization of scarce capital resources has been a significant drag on productivity. Moreover, since higher capital utilization makes workers more productive, ceteris paribus, it raises labour demand. In at least 9 of the 18 sectors, our estimates of the industry-level production function are consistent with dehoarding of labour in growing industries and involuntary hoarding or firing restrictions in declining industries. These results are interesting in the light of the preceding analysis of employment behaviour. It is estimated that about one-sixth of official working time was being lost at the end of the 1970s.

In the mature industrial economy, variations in hours of work arise largely on account of fluctuations in demand. In developing countries, substantial losses in production time may arise on account of absenteeism, industrial disputes, machine failures, or infrastructure bottlenecks such as power rationing and delivery delays. The data for the registered sector of Indian manufacturing show that, during the 1979-1987 period actual time worked was increasing at a significant trend rate of 1.64 per cent per annum. This increase was equivalent to a shift from a five- to a six-day week, but there was no overall change in official working time, which was six days in most establishments. If the hours elasticity of output is unity then this implies that one-sixth of potential production in the registered manufacturing sector was being lost on account of "undertime". This is a useful way of casting an estimate of the opportunity cost of losses in official working time. The evidence suggests that these losses were largely recuperated during the 1980s. A slackening of productivity growth in the 1990 s is consistent with the exhaustion of the gains from utilization.

\subsection{Issues of measurement of productivity growth}

Most available estimates of total factor productivity growth (TFPG) in Indian manufacturing have emerged from a growth-accounting exercise that is only valid if product markets are perfectly competitive and if there is no variation in utilization. Both of these assumptions were violated in the period under consideration. More accurate estimates of TFPG can be obtained using the marginal products estimated from a production function rather than factor shares (see Bhalotra 1998b). Since errors become magnified in the process of constructing TFPG, an instrumental variables estimator is needed to address measurement error (and endogeneity) biases. A production function is estimated by GMM (see Section 3) on a panel of industry-state data for organized manufacturing in the 1979-1987 period. This yields an average rate of (utilizationadjusted) productivity growth of about 1.8 per cent p.a. (see Bhalotra 1995, 1998b), considerably smaller than Ahluwalia's estimate of 3.4 per cent p.a. 


\subsection{Growth accounting}

It would be useful to see research that is able to perform a growth accounting exercise for the 1990s. This is as yet unavailable but we have the results for the 1980s, based upon Bhalotra (1998b). The contribution of productivity to output growth was 36-60 per cent, with the time intensity of work contributing an additional 18-25 per cent. This is remarkable, not only with regard to India's past record, but also in relation to other developing countries. Although other productivity gains may well be sustainable, time worked per worker has a naturally defined ceiling. Thus these estimates lead us to expect some slowing down in the rate of growth in output per worker once the gains from higher labour utilization have been exhausted. This is, in fact, what is observed after 1987.

\subsection{Returns to scale: scale efficiency}

If one is interested in efficiency for its own sake, measures of TFP have an enduring interest value. However, if one is interested, as we are, in tracing the impact of economic reform on productivity then it is useful to decompose both the reform package and productivity into their components. At an aggregate level, we cannot get much beyond noting changes in trend and structure that may be consistent with an overall change in economic climate.

At the disaggregate level, we can investigate more specific hypotheses. For instance, in the pre-reform era, it has been argued that Government of India policies favoured smallsized firms in a number of ways (see Lall 1987, World Bank 1986, for example). On this basis, it has been argued that Indian firms were probably characterized by unexploited scale economies and that the recent removal of restrictions on expansion of capacity and output will allow firms to grow in size and thereby achieve reductions in average cost. Fikkert and Hasan (1998) examine a sample of firm-level data for the 1975-1984 period to see how widespread the phenomenon of unexploited scale economies was before the reforms in India really took off. They find that it characterizes about a third of the sample of firms studied but that the larger firms in the sample exhibit constant returns to scale. Since, in the period studied, the larger firms tended to account for a very high percentage of output in the industry, the authors argue that the "majority of India's industrial output" is produced by firms which are scale-efficient. This is consistent with 2-digit industry-level estimates of returns to scale in Bhalotra (1995, Chapter 5). Most industries exhibit constant returns to scale. There was some evidence of decreasing returns in Petroleum and Electricity, sectors which we might well believe had factories that were larger than is efficient on account of public sector involvement. The Transport, Chemicals and Leather sectors exhibited increasing returns to scale, indicating unexploited scale economies, possibly on account of capacity or output restrictions.

Fikkert and Hasan conclude that any productivity gains arising from exploitation of scale economies made possible by the economic reforms following 1984 will have to rely upon expansion of those firms that were small in the early 1980s. As discussed earlier, there has been a continuing shift in the size structure of Indian industry in favour of relatively small firms. However, in the absence of firm-level analysis, we do not know at present whether the 1990s have seen previously small firms expand and enjoy particularly steeply declining average costs. 


\subsection{Regional productivity differentials}

Though location tends to be neglected in studies of industrial productivity, regional effects are likely to be relatively important in India on account of both its size and its level of economic development. Industrial development tends to be regionally uneven and, in India, this might be related to increasing returns effects arising from the non-uniform regional spread of public investments in infrastructure and schooling.

Time-invariant industry-state efficiency effects are recovered from the GMM estimates of the production function and averaged over time to eliminate the stochastic component of the error. Weighting by the share of each industry in total state output and averaging across industries gives the state fixed effects. Correlations of these with a set of likely regional variables were investigated.

There are substantial inter-state productivity differences even after controlling for industrial composition and these are persistent, at least through the time period analysed: 1979-1987 (see Bhalotra 1998b). Differences in manufacturing efficiency appear unrelated to public sector concentration, union density, and left-wing government (a dummy isolating Kerala and West Bengal). Significant correlations are observed of productivity with labour force composition (education, age), structural attributes (infrastructural development, agglomeration of production (as in a metropolis), unemployment rate) and industrial relations records (disputes and absenteeism). Human capital theory alone would explain only a small part of the productivity differentials. A striking case in point is Kerala, which now has virtually universal literacy compared with Bihar, for instance, which has a very low literacy rate: Bihar's manufacturing productivity is well above the national average and Kerala's well below. ${ }^{22}$

\section{Concluding remarks}

We have argued that it is inherently difficult to evaluate the effects of economic liberalization for a number of reasons, suggesting at the same time how best one may use insights from economic theory and appropriate econometric techniques to make some progress in this direction. A strong message that this paper aims to convey is that sound data analysis can get us much further than alternating speculations - which are rife in the Indian literature on this subject.

The experience of economic liberalization in India appears to have been better than in many other countries. Early reforms were initiated in the 1980s and these have been consolidated and pushed further since 1991. Both growth and productivity have accelerated in the economy as a whole and also in organized manufacturing. Capital stocks have been upgraded and investment in manufacturing has increased. Real earnings in this sector have been rising at a fairly rapid pace. Organized sector employment suffered a severe collapse in the early years of the adjustment process but has since recovered to a pace similar to that in the pre-reform era. The share of the public sector in organized manufacturing employment has been shrinking at a fairly remarkable rate. In the economy as a whole, the worker-population ratio fell in the mid-90s after having increased for the previous two decades. The shift in workforce composition from self-employment to casual wage employment that has been in progress since the 1970s continued through the 1990s.

\footnotetext{
22 These results rest on a sample of fifteen states and the correlations are only weakly significant. States are interesting as they are political entities. However, future work that analyses regional differences in productivity using more disaggregate regions (e.g. districts) is merited.
} 
The unemployment rate increased at this time but it is unclear whether this signifies a lengthening of unemployment spells and a worsening of job opportunities or whether it simply denotes a greater degree of transitional or frictional unemployment as labour is reallocated towards the more productive sectors. Average daily earnings per person per annum in the economy increased at a significant pace in rural and urban areas and for men and women. Poverty incidence declined.

The paper has pointed to directions for further research, which remains very relevant as the reforms are continuing. Analyses of labour market outcomes which attempt to uncover structural relations, which investigate the dynamics of change, and which use micro-data could make a very strong contribution to current debates on the costs and benefits of economic liberalization. 


\section{References}

Agarwal, R.N. and Goldar, B. 1995. "Economic reforms and employment in India Projections for the year 2001-02," in Indian Journal of Labour Economics (Delhi, Indian Society of Labour Economics), Vol.38, No.4, pp.577-95.

Aggarwal, A. 1991. Estimates of fixed capital stock in the registered manufacturing sector in India, Working Paper No. 937 (Ahmedabad, Indian Institute of Management).

Ahluwalia, I.J. 1985. Industrial Growth in India: Stagnation since the Mid-Sixties (Delhi, Oxford University Press).

Ahluwalia, I.J. 1991. Productivity and Growth in Indian Manufacturing (Delhi, Oxford University Press).

Akerlof, G. 1982. "Labor contracts as partial gift exchange," in Quarterly Journal of Economics (Cambridge, Massachusetts, MIT Press), 97(4) pp. 543-569.

Akerlof, G. 1984. "Gift exchange and efficiency wage theory: four views," in American Economic Review (Nashville, American Economic Association), 74(2), pp. 79-83.

Akerlof, G. and Yellen, J. 1985. "A near-rational model of the business cycle, with wage and price inertia," in Quarterly Journal of Economics (Cambridge, Massachusetts, MIT Press), 100 (suppl.) pp. 823-838.

Akerlof, G. and Yellen, J. 1986. Efficiency Wage Models of the Labour Market (Cambridge, Cambridge University Press).

Akerlof, G. and Yellen, J. 1990. "The fair wage-effort hypothesis and unemployment," in Quarterly Journal of Economics (Cambridge, Massachusetts, MIT Press ), 105(2), pp. 255-83.

Anderson, T. and Hsiao, C. 1982. "Formulation and estimation of dynamic models using panel data," in Journal of Econometrics (Amsterdam, Elsevier North Holland), 18 , pp. 47-82.

Andrews, M. 1988. "Some formal models of the aggregate labour market," in M. Beenstock (ed.): Modelling the Labour Market (New York, Chapman and Hall).

Arellano, M. and Bond, S. 1988a. Some tests of specification for panel data: Monte Carlo evidence and an application to employment equations, Working Paper No. 88/4 (London, Institute for Fiscal Studies).

Arellano, M. and Bond, S. 1988b. Dynamic panel data estimation using DPD - a guide for users, Working Paper No. 88/15 (London, Institute for Fiscal Studies).

Arellano, M. and Bond, S. 1991. "Some tests of specification for panel data: Monte Carlo evidence and an application to employment equations," in Review of Economic Studies (Oxford, Institute of Economics and Statistics, University of Oxford), 58, pp. 277-297.

Banerjee, B. 1983. "The role of the informal sector in the migration process: A test of probabilistic migration models and labour market segmentation in India," in Oxford Economic Papers (Oxford, Oxford University Press), pp. 399-422.

Banerjee, B. 1986. Rural to Urban Migration and the Urban Labour Market: A Case Study of Delhi (Bombay, Himalaya Publishing House). 
Basmann, R. L. 1960. "On finite sample distributions of generalized classical linear identifiability test statistics," in Econometrica (Evanston, The Econometric Society), 45, pp. 939-952.

Bhagwati, J. and Desai, P. 1970. India: Planning for Industrialization, Industrialization and Trade Policies since 1951 (Delhi, Oxford University Press).

Bhagwati, J. and Srinivasan, T.N. 1975. Foreign Trade Regimes and Economic Development: India (Delhi, Macmillan).

Bhagwati, J. and Srinivasan, T.N. 1993. India's Economic Reforms (New Delhi, Ministry of Finance Government of India).

Bhalla, S. 1997. "Trends in poverty, wages and employment in India," in The Indian Journal of Labour Economics (Delhi, Indian Society of Labour Economics), Vol.40, No.2.

Bhalotra, S. 1989. Wage Determination in Indian Factories, 1960-1985, M.Phil thesis (University of Oxford).

Bhalotra, Sonia R. 1995. Four Essays on the Urban Labour Market in India, D.Phil. thesis submitted to the University of Oxford.

Bhalotra, Sonia R. 1996. The Spatial Unemployment-Wage Relation Revisited: An Investigation of Interstate Urban Unemployment Differentials in India (University of Bristol), DP No. 96/409, Mar. 1996.

Bhalotra, Sonia R. 1998a. "The puzzle of jobless growth in Indian manufacturing," in Oxford Bulletin of Economics and Statistics (Oxford, Blackwell Publishers - on behalf of the Institute of Economics and Statistics, University of Oxford), 40(1), Feb. 1998.

Bhalotra, Sonia R. 1998b. "Changes in utilization and productivity in a deregulating economy," in Journal of Development Economics (Amsterdam, Elsevier North Holland), 57/2, Dec. 1998.

Bhalotra, Sonia R. 1998c. Near Rationality in Wage-Setting (London, STICERD, London School of Economics), DP No.10, Feb. 1998.

Bhalotra, Sonia R. 2000. Is Child Work Necessary? (London, London School of Economics), Development and Distribution series DP No. 26, Aug. 2000.

Bhalotra, Sonia R. with Chris Heady 2000. Child Farm Labour: The Wealth Paradox (London, London School of Economics), Development and Distribution Series Discussion Paper No. 24, July 2000.

Bhattacharya, B.B. and Mitra, A. 1993. "Employment and structural adjustment: A look at 1991 census data," in Economic and Political Weekly, (Mumbai, Sameeksha Trust), 18 Sep., pp. 1989-95.

Blanchard, O. and Summers, L.H. 1986. "Hysteresis and the European unemployment problem," in NBER Macroeconomics Annual (Cambridge, Massachusetts, MIT Press).

Blanchflower, D. and Oswald, A. 1992. International wage curves, NBER Conference on Wage Structures, London, Nov. 1992.

Blanchflower, D. and Oswald, A. 1994. The Wage Curve (Cambridge, Massachusetts, MIT Press). 
Bliss, C. 1988. "The labour market: theory and experience," in Beenstock, M. (ed.), Modelling the Labour Market, International Studies in Economic Modelling (London, Chapman and Hall).

Brahmananda, P.R. 1982. Productivity in the Indian Economy: Rising Inputs for Falling Outputs (Bombay, Himalaya Publishing House).

Brown, C. and Medoff, J. 1989. "The employer size-wage effect," in Journal of Political Economy (Chicago, University of Chicago Press), 97(5), pp. 1027-1059.

Centre for Monitoring of the Indian Economy (CMIE), Economic Intelligence Service 1991. Public Sector in the Indian Economy (Bombay), May.

Centre for Monitoring of the Indian Economy (CMIE), Economic Intelligence Service 1991. The Liberalization Process (Bombay)

Centre for Monitoring of the Indian Economy (CMIE), Economic Intelligence Service. Basic Statistics for the Indian Economy, All India (Vol.1) and States (Vol.2 ), (Bombay), several issues.

Chakravarty, S. 1974. Reflections on the growth process in the Indian economy, Mimeograph (Hyderabad, Hyderabad Administrative Staff College of India).

Chandok, H.L. and The Policy Group. 1990. India Data Base: Annual Time Series data (New Delhi, Living Media India Ltd), in 2 volumes.

Chatterji R. 1989. The Behaviour of Industrial Prices in India (New Delhi, Oxford University Press).

Chenery, H., Robinson, S. and Syrquin, M. 1986. Industrialization and Growth: A Comparative Study (New York, Oxford University Press).

Datt, R. 1993. "New economic policy and its impact on industrial relations and employment in India," in Indian Journal of Labour Economics (Delhi, Indian Society of Labour Economics), 1, pp. 66-76.

Datt, Gaurav 1999. "Has poverty declined since economic reforms?," in Economic and Political Weekly (Mumbai, Sameeksha Trust), Vol.34, No. 50.

Datt-Chaudhuri, Mrinal 1995. Labour market and social institutions in India, Working Paper No. 16, Centre for Development Economics, Delhi School of Economics.

Deshpande, L.K. 1992. "Institutional interventions in the labour market in Bombay's manufacturing sector," in T.S. Papola and G. Rodgers (eds.), Labour Institutions and Economic Development in India, Research Series 97, (Geneva, International Institute for Labour Studies, ILO).

Dev, S. Mahendra 2000. "Economic liberalization and employment in South Asia-I," in Economic and Political Weekly (Mumbai, Sameeksha Trust), 8 Jan., pp. 40-51.

Dutta-Roy, S. 1998. Lags in employment adjustment and inter-industry differentials: An analysis using dynamic inter-related factor demand functions, Discussion Paper No. 149 (Mumbai, Indira Gandhi Institute of Development Research).

Dickens, W. and Katz, L. 1987. "Inter-industry wage differences and industry characteristics," in K.Lang and J.Leonard (eds.), Unemployment and the Structure of Labour Markets (Oxford, Basil Blackwell). 
Dickens, W. and Lang, K. 1988. "The re-emergence of segmented labour market theory," in American Economic Review, Papers and Proceedings (Nashville, American Economic Association), 78(2), pp. 129-34.

Fallon, P. and Lucas, R.E.B. 1993. "Job security regulations and the dynamic demand for industrial labour in India and Zimbabwe," in Journal of Development Economics (Amsterdam, Elsevier North Holland), 40.

Fikkert, B. and Hasan, R. 1998. "Returns to scale in a highly regulated economy: evidence from Indian firms," in Journal of Development Economics (Amsterdam, Elsevier North Holland), Vol. 56, Issue 1, June, pp. 51-79.

Ghose, A.K. 1994. "Employment in organized manufacturing in India," in Indian Journal of Labour Economics (Delhi, Indian Society of Labour Economics), vol. 37(2), April-June, pp.141-62.

Ghose, A.K. 1995, "Labour market flexibility and the Indian economy," in Indian Journal of Labour Economics (Delhi, Indian Society of Labour Economics), vol.38(1), April-June, pp.55-62.

Goldar, B.N. 1986. "Import substitution, industrial concentration and productivity growth in Indian manufacturing," in Oxford Bulletin of Economics and Statistics (Oxford, Blackwell Publishers - on behalf of the Institute of Economics and Statistics, University of Oxford), 48(2).

Goldar, B. 2000. "Employment growth in organised manufacturing in India," in Economic and Political Weekly (Mumbai, Sameeksha Trust), 1 Apr., pp. 1191-1195.

Goldar, B. 2002. Report submitted to the ILO.

Government of India. 1969. Report of the Industrial Licensing Policy Enquiry Committee (Delhi).

Government of India.1979. Report of the Committee on Controls and Subsidies (Delhi).

Government of India. Annual Survey of Industries: Factory Sector (Delhi, Central Statistical Organization (CSO), Ministry of Planning), 1959-1987/88.

Government of India. Central Electricity Authority Report (Delhi).

Government of India. 1982. Rajadhyaksha Committee Report (Delhi)

Government of India. 1987. Handbook of Industrial Relations Statistics (Delhi, Ministry of Labour).

Government of India. 1993. Economic Reforms: Two Years After And The Task Ahead, (Delhi, Department of Economic Affairs, Ministry of Finance).

Government of India. Indian Labour Statistics (Delhi, Ministry of Labour), several issues.

Government of India. Indian Labour Year Book (Delhi, Labour Bureau), several issues.

Greene, W.H. 1993. Econometric Analysis (New York, Macmillan).

Griliches, Z. and Hausman, G. 1986. "Errors in variables in panel data," in Journal of Econometrics (Amsterdam, Elsevier North Holland), 31, pp. 93-118.

Hall, R. 1970. "Why is the unemployment rate so high at full employment?," in Brookings Papers on Economic Activity (Washington D.C., The Brookings Institution), 1, pp. 369-402. 
Hall, R. 1972. "Turnover in the labor force," in Brookings Papers on Economic Activity (Washington D.C., The Brookings Institution), 3, pp. 709-764.

Hall, R. 1986. "Market structure and macroeconomic fluctuations," in Brookings Papers on Economic Activity (Washington D.C., The Brookings Institution), pp. 285-338.

Hall, R. 1988. "The relation between price and marginal cost in U.S. industry," in Journal of Political Economy (Chicago, University of Chicago Press), 96, pp. 921-47.

Hamermesh, D. 1993. Labour Demand (Princeton, Princeton University Press).

Harris, J. and Todaro, M. 1970. "Migration, unemployment and development: A two-sector analysis," in American Economic Review (Nashville, American Economic Association), 60, pp. 126-142.

Helpman, E. and Krugman P. 1985. Market Structure and Foreign Trade (Cambridge, Massachusetts, MIT Press).

Helpman, E. and Krugman P. 1989. Trade Policy and Market Structure (Cambridge, MA, MIT Press).

Howell, J. and Kambhampati,U. 1999, "Liberalisation and Labour: The Fate of Retrenched Workers in the Cotton Textile Industry in India," in Oxford Development Studies (Oxford, International Development Centre, University of Oxford).

Jackman, R., Layard, R. and Savouri, S. 1991. "Mismatch: a framework for thought," in F. Padoa Schioppa (ed.), Mismatch and Labour Mobility (Cambridge, Cambridge University Press).

Joshi, V. and Little, I. 1996. India's Economic Reforms: 1991-2001 (Delhi, Oxford University Press).

Kannan, K.P. 1992. "Labour institutions and the development process in Kerala," in T.S. Papola and G. Rodgers (eds.), Labour Institutions and Economic Development in India, IILS Research Series, 97 (Geneva, ILO).

Katz, L. 1986. "Efficiency wage theories: A partial evaluation," in S. Fischer (ed.), NBER Macroeconomics Annual (Cambridge, MA, MIT Press).

Katz, L. and Summers, L. 1989. "Industry rents: Evidence and implications," in Brookings Papers on Economic Activity, Microeconomics 1989 (Washington D.C., The Brookings Institution), pp. 209-275.

Kelkar, V. and Kumar, R. 1990. "Industrial growth in the Eighties: Emerging policy issues," in Economic and Political Weekly (Mumbai, Sameeksha Trust), 27 Jan.

Krishna, K.L. 1987. "Industrial growth and productivity in India," in P.R. Brahmananda and V.R. Panchamuki (eds.), The Development Process of the Indian Economy (Bombay, Himalaya Publishing House).

Krishnamurty, J. 1987. "Unemployment in India: The broad magnitudes and characteristics," in T.N. Srinivasan and P.K. Bardhan (eds.), Rural Poverty in South Asia (New Delhi, Oxford University Press).

Krueger, A. 1974. "The political economy of the rent-seeking society," in American Economic Review (Nashville, American Economic Association). 
Krueger, A. and Summers, L. 1987. "Reflections on the inter-industry wage structure," in $\mathrm{K}$. Lang and J. Leonard (eds.), Unemployment and the structure of labour markets (Oxford, Basil Blackwell).

Krueger, A. and Summers, L. 1988. "Efficiency wages and the inter-industry wage structure," in Econometrica (Evanston, The Econometric Society), 56, pp. 259-293.

Kundu , A. 1997. "Trends and structure of employment in the 1990s: Implications for urban growth," in Economic and Political Weekly (Mumbai, Sameeksha Trust), 14 June.

Lal, D. 1988. "Excess employment in the public sector," in Indian Economic Review (Delhi, Department of Economics, Delhi School of Economics), June.

Lall, S. 1987. Learning to industrialise (London, Macmillan).

Layard, R., Nickell, S. and Jackman, R. 1991. Unemployment: Macroeconomic Performance and the Labour Market (Oxford, Oxford University Press).

Lee, E. 1996. "Globalisation and employment: Is anxiety justified?" in International Labour Review (Geneva, ILO), Vol.135, No.5.

Leibenstein, H. 1957. Economic Backwardness and Economic Growth (New York, John Wiley and Son).

Levine, D. 1992. "Can wage increases pay for themselves? Tests with a production function," in Economic Journal (Oxford, Blackwell Publishers - on behalf of the Royal Economic Society), 102(414), pp. 1102-1115.

Lewis, W.A. 1954. "Economic development with unlimited supplies of labour," in Manchester School (Manchester), 22, pp. 139-191.

Lindbeck, A. and Snower, D. 1987. "Efficiency wages versus insiders and outsiders," in European Economic Review (Amsterdam, Elsevier North Holland), 31, pp. 407-416.

Lindbeck, A. and Snower, D. 1989. The Insider-Outsider Theory of Employment and Unemployment (Cambridge, Masachusetts, MIT Press).

Little, I.M.D. 1986. "Small manufacturing enterprises in developing countries," in World Bank Economic Review (Washington D.C., World Bank), Vol.1, No.2, pp.203-35.

Lucas, R.E.B. 1988. "India's industrial policy," in R.E.B. Lucas and G. Papanek (eds.), The Indian Economy: Recent Developments and Future Prospects (New Delhi, Oxford University Press).

Marston, S. 1985. "Two views of the geographic distribution of unemployment," in Quarterly Journal of Economics (Cambridge, Massachusetts, MIT Press), 79:57-79.

Mathur, A.N. 1989. "The effects of legal and contractual regulations on employment in Indian industry," in G. Edgren (ed.), Restructuring, Employment and Industrial Relations (New Delhi, ILO-ARTEP).

Mazumdar, D. 1973. "Labour supply in early industrialization: The case of the Bombay textile industry," in Economic History Review (Oxford, Blackwell Publishers - on behalf of the Economic History Society), 2nd series, 26, pp. 477-479.

Mazumdar, D. 1976. "The rural-urban wage gap, migration and the shadow wage," in Oxford Economic Papers (Oxford, Oxford University Press). 
Mazumdar, D. 1984. "The rural-urban wage gap, migration and the working of the urban labour market: An interpretation based on a study of the workers of Bombay city," in Indian Economic Review (Delhi, Department of Economics, Delhi School of Economics), 18(2), pp. 169-198.

Mazumdar, D. 1988. "Labour and product markets," in K.B. Suri (ed.), Small Scale Enterprises in Industrial Development: The Indian Experience (New Delhi, Sage).

Mazumdar, D. 1990. "Government intervention and urban labour markets in LDCs," in Essays in Honour of I.M.D. Little (Oxford, Clarendon Press).

Mehta, A. 1988. A Survey of Living Conditions in the Slums of Delhi, Mimeograph (Delhi, Institute of Urban Planning).

Minhas, B., et al. 1987. "The cost of living in urban India," in Sankhya: The Journal of the Indian Statistical Association (Poona, Indian Statistical Association, University of Poona).

Minhas, B., et al. 1990. "The urban cost of living in Indian states," in Indian Journal of Political Economy (Pune, Indian School of Political Economy).

Minhas, B.S. and Majumdar, G. 1987. "Unemployment and casual labour in India: An analysis of recent NSS data," in Indian Journal of Industrial Relations (Pune, Indian School of Political Economy), 32(3).

Mitra, A. 1993. "Urban employment, migrant labour and structural adjustment," in Indian Journal of Labour Economics (Delhi, Indian Society of Labour Economics), Vol. 37, No.3.

Mundle, S. 1992. "The employment effect of stabilization and related policy changes in India: 1991-92 to 1993-94," in Indian Journal of Labour Economics (Delhi, Indian Society of Labour Economics), Vol. 35, No.2, July-Sep., pp. 227-37.

Mundle, S. 1993. "Unemployment and financing of relief employment in period of stabilization in India, 1992-1994," in Economic and Political Weekly (Mumbai, Sameeksha Trust), 30 Jan.

Murphy, K. and Topel, R. 1987. "Unemployment, risk and earnings: Testing for equalizing wage differences in the labor market," in K. Lang and J. S. Leonard (eds.), Unemployment and the Structure of Labor Markets (New York, Basil Blackwell).

Nagaraj, R. 1984. "Subcontracting in Indian manufacturing industries: Analysis, evidence and issues," in Economic and Political Weekly (Mumbai, Sameeksha Trust), Aug.

Nagaraj, R. 1985. "Trends in factory size in Indian industry: 1950-1980," in Economic and Political Weekly, Review of Management (Mumbai, Sameeksha Trust), Feb.

Nagaraj, R. 1990. "Industrial growth: Further evidence and towards an explanation and issues," in Economic and Political Weekly (Mumbai, Sameeksha Trust), 13 Oct., pp. 2313-2332.

Nagaraj, R. 1994. "Employment and wages in manufacturing industries: Trends, hypotheses and evidence," in Economic and Political Weekly (Mumbai, Sameeksha Trust), 22 Jan.

Nagaraj, R. 2000. "Organised manufacturing employment," discussion in Economic and Political Weekly (Mumbai, Sameeksha Trust), 16 Sep., pp. 3445-3448.

National Sample Survey Organization. Sarvekshana (New Delhi), Sep. 1990, Apr. 1988, July-Oct. 1981. 
Nayyar, D. 1993. Economic Reforms in India: A Critical Assessment (New Delhi, ILO-ARTEP).

Nickell, S. 1986. "Dynamic models of labour demand," in O. Ashenfelter and R. Layard (eds.), Handbook of Labor Economics, Vol. 1 (Amsterdam, North Holland).

Nickell, S. 1993. Competition and corporate performance, Institute of Economics and Statistics Applied Economics Discussion Paper No. 155 (University of Oxford).

Nickell, S. and Kong, P. 1992. "An investigation into the power of insiders in wage determination," in European Economic Review (Elsevier North Holland), Dec.

Nickell, S., Vainiomaki J. and Wadhwani, S. 1994. "Wages and Product Market Power," in Economica (London), Vol 61, pp 457-73.

Nickell, S. and Wadhwani, S. 1990. "Insider Forces and Wage Determination," in Economic Journal (Oxford, Blackwell Publishers - on behalf of the Royal Economic Society), 100, pp. 496-509.

Nickell, S. and Wadhwani, S. 1991. "Employment determination in British industry: Investigations using micro data," in Review of Economic Studies (Oxford, The Review of Economic Studies Ltd., Institute of Economics and Statistics, University of Oxford), 58, pp. 955-969.

Nielsen, H.S. and Dubey, A. 2002. "Child Labor: A Microeconomic Perspective". Dept. of Economics, WP \# 01-10. Aarhus School of Business, Denmark. Forthcoming in the Indian Journal of Labour Economics (Delhi, Indian Society of Labour Economics).

Oi, W.Y. 1962. "Labour as a quasi-fixed factor," in Journal of Political Economy (Chicago, University of Chicago Press), 70(6), pp. 538-555.

Papola, T.S. 1992. "Labour institutions and economic development: The case of Indian industrialization," in T.S. Papola and G. Rodgers (eds.), Labour Institutions and Economic Development in India, IILS Research Series 97 (Geneva, ILO).

Papola, T.S. 1994. "Structural adjustment, labour market flexibility and employment," in Indian Journal of Labour Economics (Delhi, Indian Society of Labour Economics), Vol.37, No.1, Jan.-Mar., pp.3-16.

Pigou, A.C. 1920. The Economics of Welfare (London, Macmillan).

Planning Commission 1990a. Employment Trends in the Nineties, mimeo (New Delhi, Government of India).

Planning Commission 1990b. Employment: Past Trends and Prospects for the 1990s, Working paper (New Delhi, Government of India), May.

Planning Commission 1992. Eighth Five-Year Plan, 1992-97 (New Delhi, Government of India), Vol. 1.

Planning Commission 2001. Report of the Task Force on Employment Opportunities, New Delhi, Government of India), June.

Pradhan, B. and Sahoo, A. 1998. Micro-Impacts of Macroeconomic and Adjustment Policies (MIMAP-India): CGE Model, mimeograph (New Delhi, National Council of Applied Economic Research).

PROBE. 1999. Public Report on Basic Education for India (Delhi, Oxford University Press). 
Ramachandran, V.K. 1997. "On Kerala's development achievements," Chapter 4 in J. Dreze, and A. Sen (eds.), Indian Development : Selected Regional Perspectives (Oxford, Oxford University Press).

Robinson, J. 1933. The Economics of Imperfect Competition (London, Macmillan).

Rodrik, D. 1992. "The limits of trade policy reform in developing countries," in The Journal of Economic Perspectives, (Nashville, American Economic Association), Vol.6.

Rosen, H.S. and Quandt, R.E. 1978. "Estimation of a disequilibrium aggregate labour market," in Review of Economics and Statistics, (Cambridge, MA, MIT Press), 60: 371-379.

Sarvekshana. 1990. "Employment and Unemployment," in Journal of the National Sample Survey Organisation (New Delhi, Central Statistical Office, Government of India).

Sen, A. 1996. "Economic reforms, employment and poverty: Trends and options," in Economic and Political Weekly (Mumbai, Sameeksha Trust), Vol. 31, Nos. 35-37.

Sengupta, A. 1995. "Financial sector and economic reforms in India", Special Article, in Economic and Political Weekly (Mumbai, Sameeksha Trust), 7 Jan.

Shapiro, C. and Stiglitz, J. 1984. "Equilibrium unemployment as a worker discipline device," American Economic Review (Nashville, American Economic Association), $74,433-444$.

Singh, M. 1993. New Economic Policy and challenges before the labour economists, Inaugural address to the 34th Conference of the Indian Society of Labour Economics, Jawaharlal Nehru University, in Indian Journal of Labour Economics (Delhi, Indian Society of Labour Economics), Vol.36, No.1.

Srivastava, A. 1987. Excess Capacity in Indian Industry, M.Phil thesis (University of Oxford).

Srivastava, V. 1996. Liberalization, Productivity and Competition: A Panel Study of Indian Manufacturing (Delhi, Oxford University Press).

Sundaram, K. 2001. "Employment-unemployment situation in the nineties: Some results from NSS 55th Round Survey," in Economic and Political Weekly (Mumbai, Sameeksha Trust), 17 Mar., pp. 931-940.

Sundaram, K. and Tendulkar, S. 1988. "Toward an explanation of interregional variations in poverty and unemployment in rural India," in T.N. Srinivasan and P.K. Bardhan (eds.), Rural Poverty in South Asia (New Delhi, Oxford University Press).

Topel, R. 1986. "Local labour markets," in Journal of Political Economy (Chicago, University of Chicago Press).

Tulpule, B. and Dutta, R. 1988. "Real wages in Indian industry," in Economic and Political Weekly (Mumbai, Sameeksha Trust), 29 Oct.

Unni, J., Lalitha, N. and Rani, U. 2001. "Economic reforms and productivity trends in Indian manufacturing," Special article, in Economic and Political Weekly (Mumbai, Sameeksha Trust), 13 Oct., pp. 3914-3922.

Vaidyanathan, A. 1994. "Employment situation: Some emerging perspectives," Special Article, in Economic and Political Weekly (Mumbai, Sameeksha Trust), 10 Dec. 
Visaria, P. and Minhas, B. 1991. "Evolving an employment policy for 1990s: What do the data tell us?," in Economic and Political Weekly (Mumbai, Sameeksha Trust), 13 Apr.

Wadhwani, S. and Wall, M. 1991. "A direct test of the efficiency wage model," in Oxford Economic Papers (Oxford, Oxford University Press), 529-547.

Westphal, L. 1981. Empirical justification for infant industry protection, World Bank Staff working paper No. 455 (Washington D.C., World Bank).

Wood, A. 1995. North-South Trade, Employment, and Inequality: Changing Fortunes in a Skill-Driven World (Oxford, Oxford University Press).

World Bank 1985. World Development Report (Washington D.C, World Bank).

World Bank 1986. India: Industrial Regulatory Policy Study (Washington D.C., Industrial Strategy and Policy Division, World Bank).

World Bank 1987. India: An Industrializing Economy in Transition (Washington, D.C.).

World Bank 1988. India: Recent Developments and Medium-Term Issues (Washington, D.C.).

World Bank 1989. India: Poverty, Employment and Social Services, A World Bank Country Study (Washington D.C.), Chapter 4.

World Bank 2000. "Increasing the demand for labour: Deregulation to increase export growth, agricultural growth and labour market flexibility," in India: Reducing Poverty, Accelerating Development (Washington, D.C.), Chapter 6. 



\section{Appendix}

\section{Alternative employment models}

Profit maximization under imperfect competition yields the employment function

$\mathrm{N}=\mathrm{N} 1(\mathrm{~K}, \mathrm{~A}, \mathrm{~W}, \sigma \mathrm{e})(\mathrm{A} .1)$

where $\mathrm{N}=$ =employment, $\mathrm{K}=$ capital, $\mathrm{A}=$ an efficiency index, $\mathrm{W}=$ product wage, $\sigma \mathrm{e}=\mathrm{a}$ cyclical demand indicator. Exploiting duality, an alternative labour demand curve is derived by minimization of a cost function subject to a given technology (Varian 1984, p.54). This is

$\mathrm{N}=\mathrm{N} 2(\mathrm{Y},(\mathrm{W} / \mathrm{C}), \mathrm{A})(\mathrm{A} .2)$

where $Y=r e a l$ value added and $C=$ user cost of capital. A third model (see Rosen and Quandt (1978), for example) that is often estimated is obtained by substituting out $\mathrm{K}$ in (A.1), using the production function $\mathrm{Y}=\mathrm{Y}(\mathrm{K}, \mathrm{L}, \mathrm{A})$. This is:

$\mathrm{N}=\mathrm{N} 3(\mathrm{Y},(\mathrm{W} / \mathrm{P}), \sigma e)(\mathrm{A} .3)$

(A3) is the model estimated by the World Bank (1989) and other studies of Indian manufacturing employment. More generally, equations (A.2) and (A.3) are the most popularly estimated, estimation of (A.1) being relatively recent and confined to a few authors based in the UK (e.g. Nickell and Wadhwani 1991, Arellano and Bond 1991). Andrews (1988) speculates that the relative neglect of (A.1) has probably arisen on account of the availability of quarterly data on output but not capital, and the difficulties of obtaining an accurate measure of capital stock. However, practical problems arise in estimation of the 'capital-free' models as well. In particular, output is highly endogenous in an employment equation, compared with capital, which may be regarded as predetermined. (A.1) is an unconditional labour demand schedule that corresponds most closely to the theoretical concept of a labour demand curve, insofar as one exists under imperfect competition. In comparison, (A.2) is a conditional demand curve, the employment decision being a question of finding the point on a given isoquant that minimizes costs given relative factor prices. This is only relevant when firms are output-constrained or when the data pertains to an aggregate closed economy operating at full employment. Equation (A.3) bears the deficiency that it has a somewhat awkward status in theory. In particular it would not be correct to read the wage elasticity derived from estimation of this model as the slope of the labour demand curvel. However, it can be interpreted as a rearranged marginal productivity condition for a CES production function without CRS (Andrews, 1988), in which case, the wage coefficient is the elasticity of substitution. 


\section{Methods of estimating TFPG}

Let the production of real value added $(\mathrm{Y})$ be described as

$y=b n n+b k k+b h h+n(1)$

which is a log-linear approximation to a fairly general technology. Lowercase letters denote logarithms, $\mathrm{N}$ is employment, $\mathrm{K}$ is capital stock, $\mathrm{H}$ is actual hours worked per worker (henceforth, hours) and $\mathrm{n}$ is a residual which will be referred to as total factor productivity. The vector $b$ is the set of estimated coefficients.

\section{Factor Shares - The Solow Index}

The Solow index commonly used to estimate TFPG is

DtfpSolow $=$ Dy $-\mathrm{aDn}-(1-\mathrm{a}) \mathrm{Dk}(1)$

where the variables are in logarithms, $\mathrm{y}$ is value added, $\mathrm{n}$ is employment, $\mathrm{k}$ is capital stock, $a$ is the share of labour in value added, and constant returns to scale are

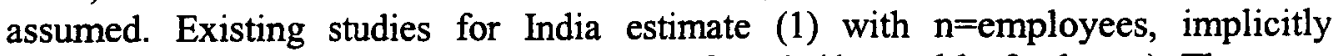
ignoring any variation in the time intensity of work (denoted $h$, for hours). The more common assumption, dating from Solow (1957) and Abramowitz (1950) is $n=$ total manhours, or $\mathrm{bh}=\mathrm{a}$. Estimates of the production technology for India (Bhalotra 1998b) show that we cannot reject the restriction that $b h=1$. Setting $b h=a$ or, alternatively, $b h=1$, gives two further Solow measures of TFPG:

Dtfp1Solow $=$ Dy - aDm $-(1-a) D k$

Dtfp2Solow $=\mathrm{D}(\mathrm{y}$-hours $)-\mathrm{aDn}-(1-\mathrm{a}) \mathrm{Dk}(3)$

In (2), $m=$ total man-hours=(employment+hours). This is the more natural formulation when $a$ is the share of labour in value added. However, (3) may be a closer approximation to the actual production function.

\section{Output elasticities - The Modified Index}

The Solow index assumes perfectly competitive product markets, whence factor shares measure the contributions of the factors to value added. Estimates of the production function for India indicate a positive mark-up, evidence of imperfect competition in Indian manufacturing. In this more general case, output elasticities should be used in place of factor shares. This gives 

Working papers

are preliminary documents

circulated to stimulate discussion

and obtain comments...

\section{Integration}

\section{FOR MORE INFORMATION}

Policy Integration Department

International Labour Office

4 , route des Morillons

CH-1211 Geneva 22

Switzerland

Tel.: (+41 22) 7996030

Fax: (+41 22) 7998044

International Policy Group

Tel.: (+41 22) 7998429

Fax: $(+4122) 7998579$

E-mail: integration@ilo.org

Internet: www.ilo.org 